Article

\title{
Landslide Susceptibility Mapping for the Muchuan County (China): A Comparison Between Bivariate Statistical Models (WoE, EBF, and IoE) and Their Ensembles with Logistic Regression
}

\author{
Renwei $\mathrm{Li}^{*}$ and Nianqin Wang * \\ College of Geology and Environment, Xi'an University of Science and Technology, Xi'an 710054, China \\ * Correspondence: 17209074018@stu.xust.edu.cn (R.L.); wangnianqin@xust.edu.cn (N.W.)
}

Received: 7 May 2019; Accepted: 3 June 2019; Published: 5 June 2019

\begin{abstract}
The main purpose of this study is to apply three bivariate statistical models, namely weight of evidence (WoE), evidence belief function (EBF) and index of entropy (IoE), and their ensembles with logistic regression (LR) for landslide susceptibility mapping in Muchuan County, China. First, a landslide inventory map contained 279 landslides was obtained through the field investigation and interpretation of aerial photographs. Next, the landslides were randomly divided into two parts for training and validation with the ratio of 70/30. In addition, according to the regional geological environment characteristics, twelve landslide conditioning factors were selected, including altitude, plan curvature, profile curvature, slope angle, distance to roads, distance to rivers, topographic wetness index (TWI), normalized different vegetation index (NDVI), land use, soil, and lithology. Subsequently, the landslide susceptibility mapping was carried out by the above models. Eventually, the accuracy of this research was validated by the area under the receiver operating characteristic (ROC) curve and the results indicated that the landslide susceptibility map produced by EBF-LR model has the highest accuracy (0.826), followed by IoE-LR model (0.825), WoE-LR model (0.792), EBF model (0.791), IoE model (0.778), and WoE model (0.753). The results of this study can provide references of landslide prevention and land use planning for local government.
\end{abstract}

Keywords: Landslide susceptibility; weights of evidence; evidence belief function; index of entropy; logistic regression; Geographic Information Systems (GIS)

\section{Introduction}

As one of the most frequently-occurring geological disasters in the world, landslides have triggered a series of threats to human society including casualties, economic losses, infrastructure destruction, and geological environment problems [1-3]. Therefore, to reduce the losses, it is absolutely necessary to study the landslide susceptibility in a region [4,5]. According to the previous researches, landslide susceptibility can be roughly defined as the landslide occurrence probability in an area under the synergistic effect of a number of regional geological environmental factors [6,7]. Due to the large number and variability of landslide conditioning factors involved in the process, it is difficult to predict landslide-prone areas. What is known is that many geological and topographic conditions can influence the occurrence of landslides, such as formation lithology, faults, hydrology, attitude, slope angle, soil, and vegetation [8,9]. As landslide susceptibility mapping is the first and foremost step in landslide prevention, numerous researchers have been devoted to landslide susceptibility mapping in past years [10-14]. In general, the methods used in previous studies can be roughly divided into two types: qualitative and quantitative, for example, analytic hierarchy process (AHP) is the most commonly-used qualitative approach in landslide susceptibility mapping [14-16]. In recent 
years, machine learning method has been gradually applied in landslide susceptibility mapping researches, such as artificial neural network (ANN) [17-19], support vector machine (SVM) [20-22], logistic model tree (LMT) $[23,24]$, rotation forest (RF) [25,26], classification and regression tree (CART) $[27,28]$, adaptive neuro-fuzzy inference systems (ANFIS) [29,30], and genetic algorithm (GA) [31,32]. Furthermore, statistical approach is another widely-used model which can also be divided into two types: bivariate and multivariate. In statistical approaches, the weight of each class of every factor was calculated by overlying the landslide inventory map and landslide conditioning factors map [33,34]. The frequently-used statistical approaches are frequency ratio (FR) [35-37], logistic regression (LR), evidential belief function (EBF) [38,39], weights of evidence (WoE) [40,41], certainty factor (CF) [42,43], and information value (IV) [44,45].

In this paper, three bivariate statistical methods, namely weight of evidence (WoE), evidence belief function (EBF), index of entropy (IoE), coupled with logistic regression (LR) were introduced to carry out the landslide susceptibility mapping in Muchuan County, which lies in the southeast of Sichuan Province, China. All the approaches were first applied in Muchuan County and the main purpose of this article is to obtain the landslide susceptibility maps through the above models. The main difference between this study and literatures referenced above is to achieve accurate landslide susceptibility maps for Muchuan County through the combination and comparison of those models. At last, the results were validated by the area under the receiver operating characteristic (ROC) curve.

\section{Geological and Geomorphological Setting}

The study area (Muchuan County) is located in Leshan city, Sichuan Province, China. It lies between longitudes $103^{\circ} 21^{\prime}$ to $104^{\circ} 37^{\prime} \mathrm{E}$, and latitudes $28^{\circ} 49^{\prime}$ to $29^{\circ} 31^{\prime} \mathrm{N}$ (Figure 1). It covers an area of $1408 \mathrm{~km}^{2}$. The attitude of the study area ranges from 290 to $1866 \mathrm{~m}$ above the sea level. The annual rainfall is $1332 \mathrm{~mm}$ and it mainly concentrate from June to September. Geologically, the study area located in the Muchuan-Mabian arcuate fold belt of southwest of Yangtze para-platform where folds are developed more than faults. The study area is covered by various types of lithological units such as mudstone, sandstone, siltstone, and coal measure strata (Table 1).

Table 1. Formations.

\begin{tabular}{|c|c|c|}
\hline Group & Lithology & Geologic Ages \\
\hline A & $\begin{array}{l}\text { Brick red massive allochemical rock, sandstone sandwiched mudstone and siltstone } \\
\text { Brick red thin-thick layer silty fine-grained arkose, mudstone } \\
\text { Brick red massive allochemical rock, sandstone sandwiched mudstone and siltstone }\end{array}$ & Cretaceous \\
\hline B & $\begin{array}{l}\text { Grayish-purple arkose, siltstone sandwiched mud shale and coquina } \\
\text { Bright red mudstone, sandwiched with the same color sandstone and siltstone } \\
\text { Grayish-purple arkose, siltstone sandwiched mud shale and coquina }\end{array}$ & Jurassic \\
\hline $\mathrm{C}$ & Yellow-gray feldspar-quartz sandstone interbedded with purple-red mudstone & Jurassic \\
\hline $\mathrm{D}$ & Magenta mudstone, quartz sandstone, and siltstone sandwiched biosparite and marl & Jurassic \\
\hline $\mathrm{E}$ & $\begin{array}{l}\text { Gray sandstone, siltstone, and mudstone } \\
\text { Grayish-yellow debris-feldspar, siltstone, mudstone, and coal }\end{array}$ & Triassic \\
\hline $\mathrm{F}$ & Yellow-gray medium-thick dolomite sandwiched limestone, gypsum salt, and salt-soluble breccia & Triassic \\
\hline G & Limestone, dolomite, and shale & Triassic \\
\hline $\mathrm{H}$ & Yellow-green siltstone sandwiched with mudstone and coal & Permian \\
\hline I & The upper part is limestone and dolomite and the lower part is shale sandwiched siltstone & Permian \\
\hline $\mathrm{J}$ & $\begin{array}{c}\text { Grayish-green dense amygdaloidal basalt sandwiched picrite, tuff sand mudstone, shed coal and } \\
\text { siliceous rock }\end{array}$ & Permian \\
\hline
\end{tabular}




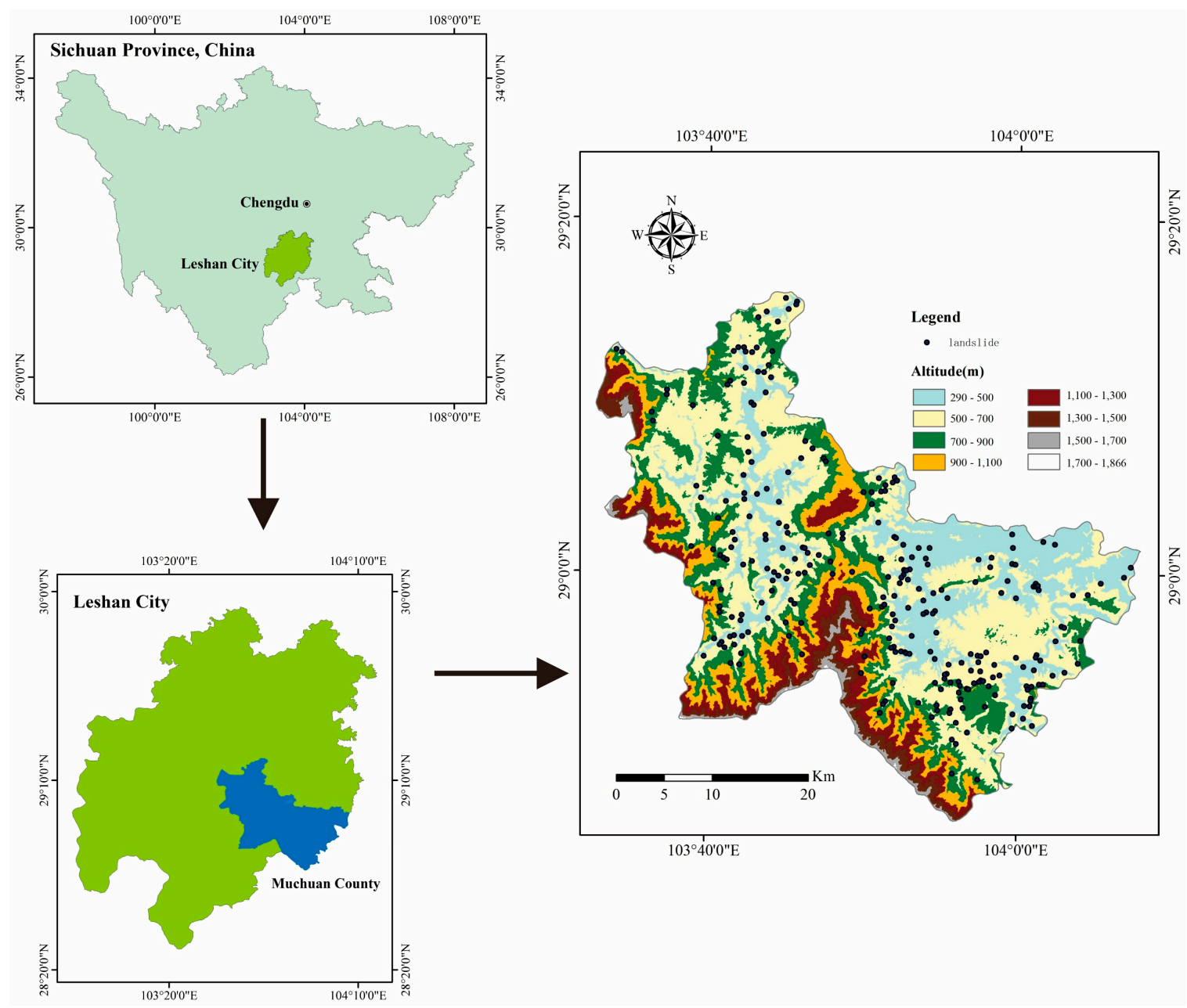

Figure 1. Geographical position of study area.

\section{Materials and Methods}

\subsection{Landslide Conditioning Factors}

According to the regional geological environment characteristics and previous studies [46-48], 12 landslide conditioning factors were selected, including altitude, plan curvature, profile curvature, slope angle, distance to roads, distance to rivers, topographic wetness index (TWI), normalized different vegetation index (NDVI), land use, soil, and lithology. A digital elevation model (DEM) with $30 \times 30 \mathrm{~m}$ resolution provided by the Geospatial Data Cloud of Chinese Academy of Sciences (GSCloud) was introduced to generate a series of topographic factors, such as altitude, plan curvature, profile curvature, slope angle, slope aspect, and TWI [49]. The Landsite-8 image (LC81300402018099LGN00, 9 April 2018 ) with resolution of $30 \times 30 \mathrm{~m}$ was obtained from the same place as DEM and was used to extract the NDVI map using ArcGIS software [50]. The land use map was extracted from the regional land use map at a scale of 1:100,000 provided by local Land and Resources Bureau. The distance to rivers and distance to roads were obtained from the topographic map with the scale of 1:50,000 that provided by the same place as land use map. The soil map was extracted from the regional soil map at a scale of 1:1,000,000 that provided by Institute of Soil Science, Chinese Academy of Sciences (ISSCAS) [51]. The lithology map was extracted from the regional lithology map with the scale of 1:200,000 that provided by National Geological Archives of China (NGAC) [52]. Moreover, satellite images from the Google Earth pro 7.1 were also applied to assist the research. All the data mentioned above were processed and used to generate the landslide conditioning factors in ArcGIS software. 
As mentioned above, DEM was used to extract topographic related landslide conditioning factors, such as altitude, plan curvature, profile curvature, slope angle, slope aspect, and TWI. Altitude is one of the most frequently used factors in landslide susceptibility mapping [53-55]. The main reason is that the altitude can influence the topographic attributes which lead to spatial variability of different landscape processes. In addition, the altitude can also influence the vegetation distribution which has a close relationship with landslide. In this paper, the altitude was divided into eight categories, i.e. 290-500, 500-700, 700-900, 900-1100, 1100-1300, 1300-1500, 1500-1700, and 1700-1866 m (Figure 2a).

Plan curvature is considered as an important factor which controls the aggregation and separation of topography and has a direct influence on the velocity of water flow and thus erosion $[41,56,57]$. In this paper, plan curvature ranged from -26.54 to 26.21 and was reclassified into five categories, i.e. -26.54 to $-3.17,-3.17$ to $-1.10,-1.10$ to $0.56,0.56$ to 2.62 , and 2.62 to 26.21 (Figure 2b).

Profile curvature is the curvature in vertical plane parallel of the slope section which also has an influence on the velocity of water flow and thus erosion [58-60]. In this study, the profile curvature ranged from -34.72 to 29.66 and was reclassified into five categories, i.e. -34.72 to $-4.17,-4.17$ to -1.39 , -1.39 to $0.88,0.88$ to 3.66 , and 3.66 to 29.66 (Figure 2 c).

Slope angle directly affects the stability of slope and it is considered as one of the most important factors in landslide susceptibility mapping [61-63]. In this study, the slope angle ranged from 0 to $77.14^{\circ}$ and was reclassified into eight categories, i.e. $0^{\circ}-10^{\circ}, 10^{\circ}-20^{\circ}, 20^{\circ}-30^{\circ}, 30^{\circ}-40^{\circ}, 40^{\circ}-50^{\circ}, 50^{\circ}-60^{\circ}$, $60^{\circ}-70^{\circ}$, and $70^{\circ}-77.14^{\circ}$ (Figure $2 \mathrm{~d}$ ).

Slope aspect affects the slope stability indirectly via hydrologic processes, such as the direction of rainfall and sunshine [64-66]. In addition, the slope aspect can also influence the weathering process and vegetation distribution $[67,68]$. In this study, the slope was classified into nine categories, i.e. flat $(-1)$, north $\left(337.5^{\circ}-360^{\circ}, 0-22.5^{\circ}\right)$, northeast $\left(22.5^{\circ}-67.5^{\circ}\right)$, east $\left(67.4^{\circ}-112.5^{\circ}\right)$, southeast $\left(112.5^{\circ}-157.5^{\circ}\right)$, $\operatorname{south}\left(157.5^{\circ}-202.5^{\circ}\right)$, southwest $\left(202.5^{\circ}-247.5^{\circ}\right)$, west $\left(247.5^{\circ}-292.5^{\circ}\right)$, and northwest $\left(292.5^{\circ}-337.5^{\circ}\right)$ (Figure 2e).

Distance to roads is considered as an important factor in landslide susceptibility mapping as it is an anthropogenic factor which can change surface configuration, cause the slope to lose support and then induced the occurrence of landslide [69-72]. In this study, five different buffer zones were generated by the interval of $500 \mathrm{~m}$ in ArcGIS software, i.e. 0-500, 500-1000, 1000-1500, 1500-2000 and $>2000 \mathrm{~m}$ (Figure 2f).

Distance to rivers affect the hydrologic processes of the slope. The closer to the river, the more the slope is eroded by the river. It can negatively affect the stability of slope via eroding the toe of slope [73-76]. In this study, five different buffer zones were classified by the interval of $200 \mathrm{~m}$ in ArcGIS software, i.e. 0-200, 200-400, 400-600, 600-800, and >800 m (Figure 2g).

TWI is an important conditioning factor in landslide occurrence. It is a factor of soil moisture that has a profound influence on the most of landslides [77-79]. In this study, the TWI ranged from 0.35 to 14.58 and was reclassified into five categories, i.e. 0.35 to $1.63,1.63$ to $2.41,2.41$ to $3.36,3.36$ to 4.81 , and 4.81 to 14.58 (Figure 2h).

NDVI is a factor that indicates the vegetation growth status and vegetation coverage. The negative value shows the ground is cover by water, snow and so on. 0 means the ground is cover by rock or bare soil. A positive value indicates the ground is cover by vegetation, which increases with the increase of coverage. The higher the NDVI value, the lower the possibility of landslide occurrence [80-82]. In this study, the NDVI ranged from -0.13 to 0.58 and was reclassified into five categories, i.e. -0.13 to 0.13 , 0.13 to $0.24,0.24$ to $0.30,0.30$ to 0.37 , and 0.37 to 0.58 (Figure 2i).

The other important landslide-related factor in landslide susceptibility mapping is land use and it has been widely applied in previous researches [83-85]. In this study, the land use map was obtained through the interpretation of Landsat 8 image. Finally, the land use was reclassified into six categories, i.e. farm land, forest land, grass land, water, residential areas, and bare land (Figure 2j). 
Soil is the common component that constitutes of slope. Different soil has different physical and mechanical properties and it can affect the surface water infiltration and groundwater flow [86-89]. The study area has ten soil types (Figure $2 \mathrm{k}$ ).

Lithology is also considered as an important landslide-related factor in landslide susceptibility mapping [90]. The variation of lithology may lead to the variation of strength and permeability of rock stratum. Usually, the landslide slides along a rock stratum with low strength and poor permeability [91-94]. The study area has ten lithology types (Figure 21).
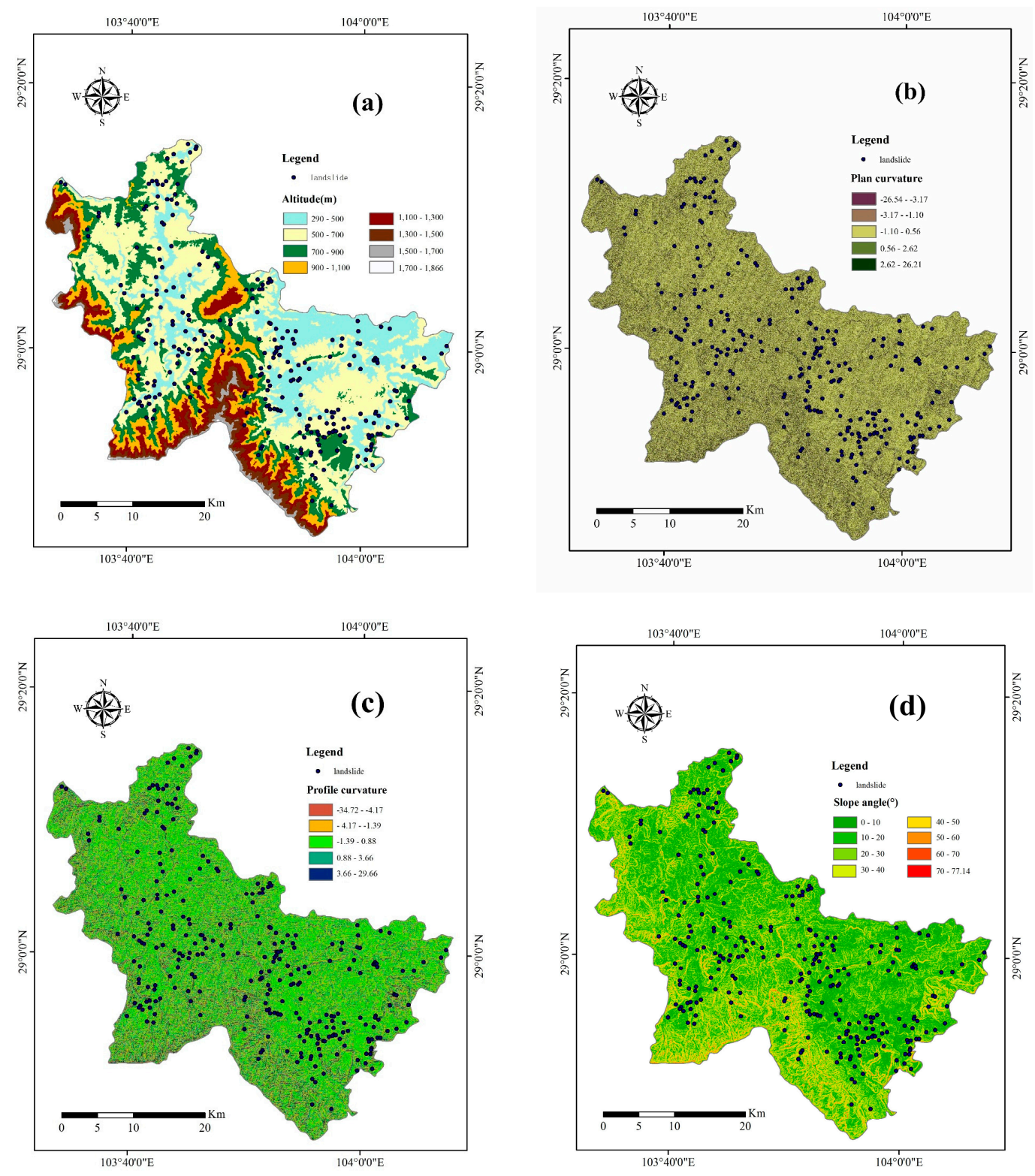

Figure 2. Cont. 

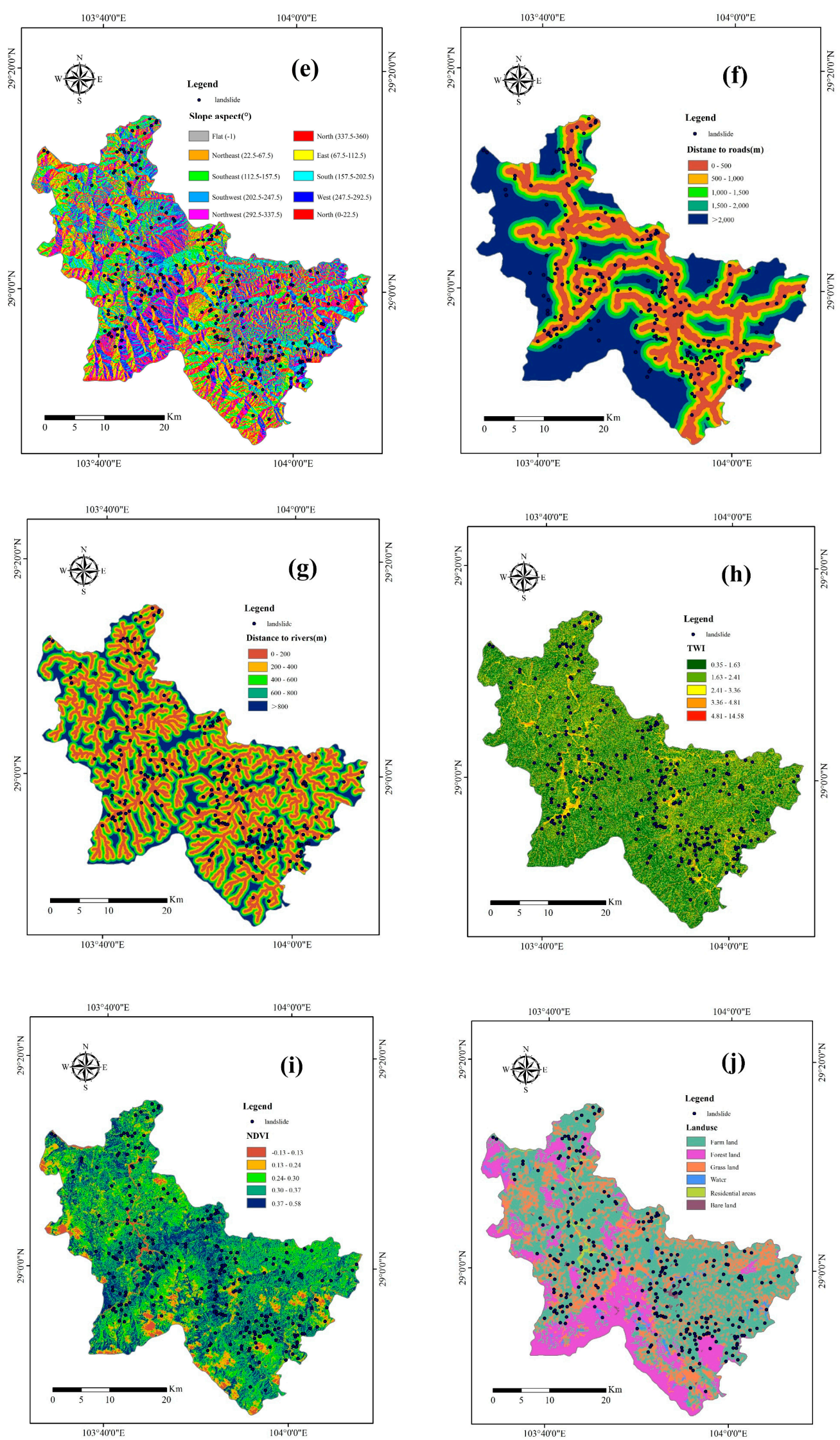

Figure 2. Cont. 

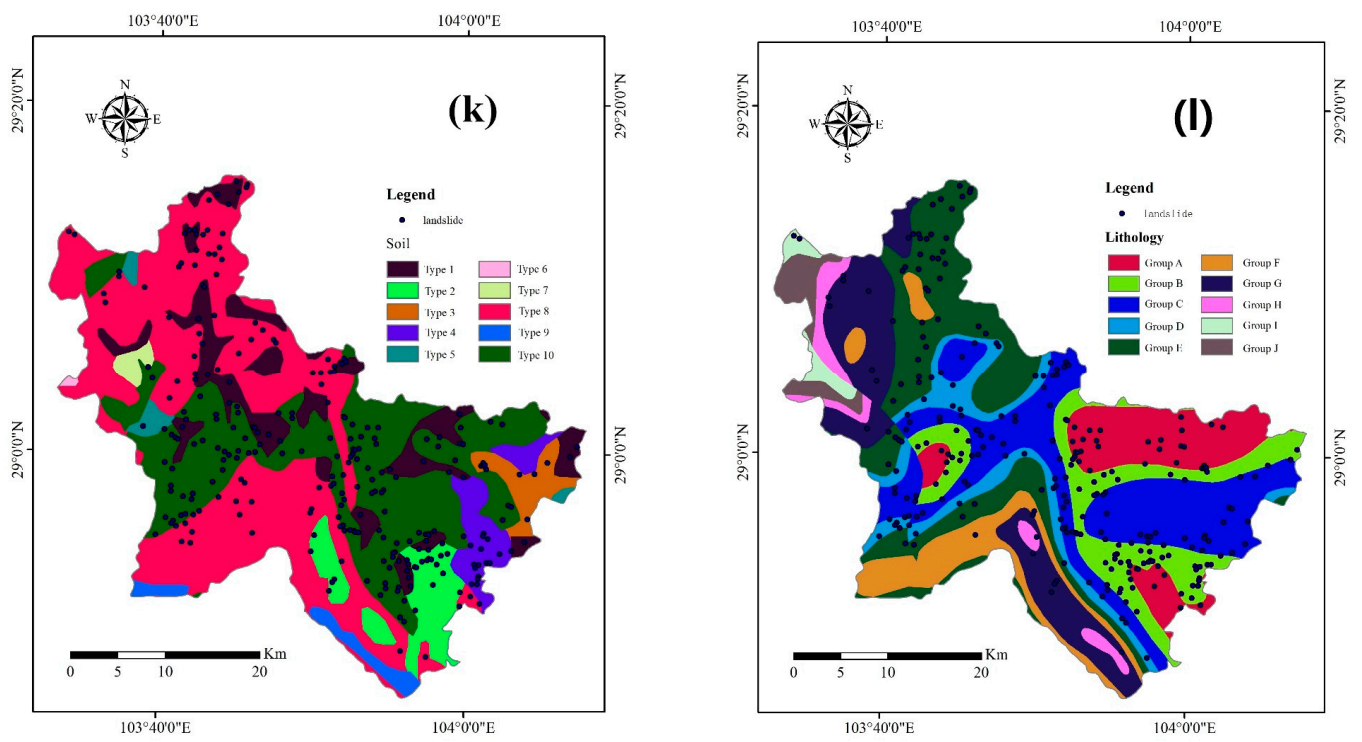

Figure 2. Landslide conditioning factors: (a) Altitude; (b) plan curvature; (c) profile curvature; (d) slope angle; (e) slope aspect; (f) distance to roads; (g) distance to rivers; (h) topographic wetness index (TWI); (i) normalized different vegetation index (NDVI); (j) land use; (k) soil; (l) lithology.

\subsection{Preparation of Training and Validation Datasets}

Chung and Pham indicated that model validation process must be established on the basis of dividing the dataset $[95,96]$. Therefore, it was necessary to split the dataset into two parts in landslide susceptibility mapping. The first part was applied to build the models called training dataset and the rest was used to verify the model performances named validation dataset. However, there are no general rules for splitting the proportion of training and validation datasets [97]. According to the previous studies [98-100], the most commonly-used ratio (70/30) was introduced to select training and validation datasets, respectively. Finally, the training dataset was built by overlaying the $70 \%$ (195) of landslides onto 12 landslide conditioning factor layers. Oppositely, the rest of the landslides were used to construct the validation dataset. After the preparation of training and validation datasets, all the data analysis processes were carried out in ArcGIS software and the results were validated by Wilcoxon signed-rank test and ROC curve.

\subsection{Weight of Evidence}

Weight of evidence (WoE) is a spatial information integration model based on the Bayesian probability model, which can evaluate and predict objects with spatial significance and is one of the most important techniques in mineral potential assessment $[39,101]$. During the past years, the WoE model has been gradually applied in environmental evaluation, geological hazard and the survey of forest pest [102-104]. In this paper, the WoE model was introduced to landslide susceptibility research for its great suitability in analyzing the relationships between spatial distribution of landslides and conditioning factors.

The original description of mathematical formulation of WoE model was introduced by Bonham-Carter $[105,106]$. In WoE modeling, the weight of each conditioning factor class was calculated based on the occurrence of landslides within the area [107]. The weight in this paper can be separated into positive weight and negative weight and their calculation formulas are presented in Equation (1) and Equation (2), respectively.

$$
W_{i}^{+}=\operatorname{In} \frac{p\{B \mid L\}}{P\{B \mid \bar{L}\}}
$$




$$
W_{i}^{-}=\operatorname{In} \frac{p\{\bar{B} \mid L\}}{P\{\bar{B} \mid \bar{L}\}}
$$

where $P$ is the probability. In represents the natural logarithm. B is the presence of potential landslide predictive factor, while $\bar{B}$ is the absence of potential landslide predictive factor. $L$ is the presence of landslide. $\bar{L}$ is the absence of landslide. $W_{i}^{+}$means positive weight that shows a positive relationship between predictable variable and landslide and $W_{i}^{-}$indicates the correlation of them is negative.

The difference between $W_{i}^{+}$and $W_{i}^{-}$is the weight contrast, which magnitude indicates all the spatial association between predictable variable and landslides. It's computational equation is presented in Equation (3).

$$
C_{i}=W_{i}^{+}-W_{i}^{-}
$$

where $C_{i}$ is the weight contrast of $W_{i}^{+}$and $W_{i}^{-}$.

\subsection{Evidential Belief Function}

The Dempster-Shafer theory (DST) of evidence proposed by Shafer in 1976 is regarded as a spatial integration model with mathematical representation. The framework of evidence belief function (EBF) model is developed from DST of evidence $[108,109]$. The EBF model usually applied as an effective approach to mineral potential mapping for its powerful ability of analyzing the incomplete data [110]. In addition, it also has the power to combine multiple sources of evidence. The model can evaluate how close the evidence proves rather than give the probabilities that the assumption is true [111]. EBF model is consisted of four basic functions, namely the degree of belief (Bel), the degree of disbelief (Dis), the degree of uncertainly (Unc) and the degree of plausibility (Pls). In recent years, EBF model has been widely and successfully applied in landslide susceptibility mapping [112-114]. In this paper, the basic functions of EBF model were determined by overlying the landslide inventory map on each landslide conditioning factor layer and the Bel was regard as the symbol of relationship between landslide and landslide conditioning factor. The equations of the above four functions can be expressed in Equations (4)-(8).

$$
\begin{gathered}
B e l=\frac{B e l_{1}+B e l_{2}+\ldots+B e l_{n}}{1-\sum_{i=2}^{n} B e l_{i-1} D i s_{i}-D i s_{i-1} B e l_{i}} \\
D i s=\frac{D i s_{1}+D i s_{2}+\ldots+D i s_{n}}{1-\sum_{i=2}^{n} B e l_{i-1} D i s_{i}-D i s_{i-1} B e l_{i}} \\
\text { Unc = } \frac{\sum_{i=2}^{n}\left(U n c_{i-1} U n c_{i}+B e l_{i-1} U n c_{i}+B e l_{i} U n c_{i-1}+D i s_{i-1} U n c_{i}+D i s_{i} U n c_{i-1}\right)}{1-\sum_{i=2}^{n} B e l_{i-1} D i s_{i}-D i s_{i-1} B e l_{i}} \\
P l s=B e l+U n c \\
B e l+U n c+D i s=1
\end{gathered}
$$

where $B e l_{i}$ is the degree of belief of $i$ th conditioning factor. Dis $s_{i}$ is the degree of disbelief of $i$ th factor. Similarly, $U n c_{i}$ means the degree of uncertainty of $i$ th factor. Pls shows the upper limits of probability. Oppositely, Dis shows the lower limits of probability.

\subsection{Index of Entropy}

The third model used in this paper is the index of entropy (IoE) model that is based on the principle of bivariate analysis $[115,116]$. It can calculate the weight of each input variable and the weight indicates the disorder of which parameter is the most relevant for the occurrence of landslide 
in a natural environment. The equations applied to calculate the weight of conditioning factors are expressed in Equations (9)-(14).

$$
\begin{gathered}
P_{i j}=\frac{b}{a} \\
\left(P_{i j}\right)=\frac{P_{i j}}{\sum_{j=1}^{S_{j}} P_{i j}} \\
H_{j}=-\sum_{i=1}^{S_{j}}\left(P_{i j}\right) \log _{2}\left(P_{i j}\right) j=1,2,3, \ldots, n \\
H_{j \max }=\log _{2} S_{j} \\
I_{j}=\frac{H_{j \max }-H_{j}}{H_{j \max }}, I=(0,1) j=1,2,3, \ldots, n \\
W_{j}=I_{j} \times P_{i j}
\end{gathered}
$$

where $a$ is the domain percentage. $b$ is the landslide percentage. $P_{i j}$ is the probability density of class $i$ of factor $j . H_{j \max }$ and $H_{j}$ are the entropy values of factor $j . S_{j}$ is the amount of classes factor $j . I_{j}$ is the information coefficient factor $j . W_{j}$ is the weight for the parameter as a whole.

\subsection{Logistic Regression}

Logistic regression (LR) model believes several physical parameters may affect the probability of landslide occurrence [117-119]. The LR model allows developing a multivariate regression correlation between a dependent variable and several independent variables [120,121]. The advantage of LR model is that through the addition of suitable link function to the usual linear regression model, the variables can be continuous, discontinuous, or both, and they do not to obey normal distribution [122,123]. In the present study, the main purpose of the LR model is to find the most suitable approach to obtain the relationship of the presence or absence of landslides with a series of independent variables. The relationship between the landslide occurrence and independent variables (landslide conditioning factors) can be described in Equation (15).

$$
P=\frac{1}{1+\exp (-Z)}
$$

where $P$ is the probability of landslide occurrence and its range is 0 to $1 . Z$ is a linear sum of constants that obtained through the product of the independent variables and their respective coefficients. The interval of $Z$ is $-\infty$ to $+\infty$ and the computational equation is shown in Equation (16).

$$
Z=\alpha+\beta_{1} x_{1}+\beta_{2} x_{2}+\beta_{3} x_{3}+\ldots+\beta_{n} x_{n}
$$

where $\alpha$ is a constant, $\beta_{i}(i=1,2,3, \ldots, n)$ is the coefficient, and $x_{i}(i=1,2,3, \ldots, n)$ is the independent variable.

\section{Results and Analysis}

\subsection{Multicollinearity Analysis}

Before the data analysis, the most important step is to verify whether the landslide conditioning factors are correlated with each other and the size of the correlation between them. If there exists a strong correlation between two or more factors, it will make it difficult to predict landslide occurrence [124]. Therefore, the multicollinearity analysis was introduced to illustrate the connections between the factors [125]. There are two commonly used statistical parameters in multicollinearity analysis, namely 
tolerance (TOL) and variance inflation factor (VIF), and they are a pair of reciprocals. According to previous studies $[6,126]$, it can be considered that variables are mutually independent when the range of TOL value is 0.1 to 1 . The multicollinearity analysis results of landslide conditioning factors under different models are calculated by SPSS software (Table 2) [127]. The results indicate all the factors are independent from each other. The calculation formulas of TOL and VIF are shown in Equation (16) and Equation (17), respectively. In addition, the results of correlation between landslides and conditioning factors calculated by WoE, EBF and IoE models are shown in Table 3.

$$
\begin{gathered}
\mathrm{TOL}=\frac{1}{\mathrm{VIF}} \\
\mathrm{VIF}=\frac{1}{1-R_{i}^{2}}
\end{gathered}
$$

where $R_{i}$ is the negative correlation coefficient of the $i$ th independent variable that makes regression analysis on other independent variables.

Table 2. Analysis. WOE: weight of evidence; EBF: evidence belief function; IoE: index of entropy; TOL: tolerance; VIF: variance inflation factor.

\begin{tabular}{cccccccc}
\hline \multirow{2}{*}{ Number } & \multirow{2}{*}{ Factors } & \multicolumn{2}{c}{ WOE } & \multicolumn{2}{c}{ EBF } & \multicolumn{2}{c}{ IoE } \\
\cline { 3 - 7 } & & TOL & VIF & TOL & VIF & TOL & VIF \\
\hline 1 & Slope aspect & 0.921 & 1.086 & 0.922 & 1.085 & 0.924 & 1.083 \\
2 & Altitude & 0.835 & 1.197 & 0.659 & 1.517 & 0.659 & 1.517 \\
3 & Land use & 0.861 & 1.162 & 0.830 & 1.206 & 0.828 & 1.208 \\
4 & Lithology & 0.691 & 1.447 & 0.577 & 1.733 & 0.577 & 1.732 \\
5 & NDVI & 0.980 & 1.020 & 0.953 & 1.050 & 0.954 & 1.048 \\
6 & Plan curvature & 0.898 & 1.114 & 0.894 & 1.118 & 0.905 & 1.105 \\
7 & Profile curvature & 0.912 & 1.097 & 0.896 & 1.116 & 0.929 & 1.076 \\
8 & Distance to rivers & 0.981 & 1.020 & 0.969 & 1.032 & 0.973 & 1.028 \\
9 & Distance to roads & 0.764 & 1.309 & 0.706 & 1.416 & 0.707 & 1.414 \\
10 & Slope angle & 0.869 & 1.151 & 0.802 & 1.247 & 0.818 & 1.222 \\
11 & Soil & 0.798 & 1.253 & 0.717 & 1.394 & 0.723 & 1.384 \\
12 & TWI & 0.916 & 1.091 & 0.860 & 1.163 & 0.863 & 1.158 \\
\hline
\end{tabular}

Table 3. Between landslides and conditioning factors using WoE, EBF, and IoE models. Bel: belief; Dis:

\begin{tabular}{|c|c|c|c|c|c|c|c|c|c|c|c|}
\hline Factors & Class & $\begin{array}{c}\text { No. of } \\
\text { Landslide }\end{array}$ & $\begin{array}{l}\text { No. of Pixels } \\
\text { in Domain }\end{array}$ & $\mathbf{W}^{+}$ & $\mathbf{W}^{-}$ & C & Bel & Dis & Unc & Pls & $\mathbf{W}_{\mathbf{j}}$ \\
\hline \multirow[t]{6}{*}{ Altitude (m) } & $290-500$ & 42 & 727325 & 0.035 & -0.009 & 0.044 & 0.270 & 0.125 & 0.605 & 0.875 & 0.190 \\
\hline & $500-700$ & 110 & 1330115 & 0.394 & -0.352 & 0.746 & 0.387 & 0.089 & 0.524 & 0.911 & \\
\hline & $900-1,100$ & 5 & 354758 & -1.375 & 0.081 & -1.456 & 0.066 & 0.137 & 0.797 & 0.863 & \\
\hline & $1,100-1,300$ & 0 & 246634 & 0.000 & 0.073 & 0.000 & 0.000 & 0.000 & 1.000 & 1.000 & \\
\hline & $1,300-1,500$ & 0 & 144601 & 0.000 & 0.042 & 0.000 & 0.000 & 0.000 & 1.000 & 1.000 & \\
\hline & $1,500-1,700$ & 0 & 50150 & 0.000 & 0.014 & 0.000 & 0.000 & 0.000 & 1.000 & 1.000 & \\
\hline \multirow{4}{*}{ Plan curvature } & $-3.17--1.10$ & 39 & 592578 & 0.166 & -0.037 & 0.203 & 0.228 & 0.191 & 0.582 & 0.809 & \\
\hline & $-1.10-0.56$ & 75 & 1660025 & -0.211 & 0.158 & -0.369 & 0.156 & 0.232 & 0.612 & 0.768 & \\
\hline & $0.56-2.62$ & 62 & 909888 & 0.200 & -0.081 & 0.282 & 0.236 & 0.182 & 0.582 & 0.818 & \\
\hline & $2.62-26.21$ & 13 & 208791 & 0.110 & -0.007 & 0.118 & 0.215 & 0.196 & 0.588 & 0.804 & \\
\hline \multirow[t]{3}{*}{ Profile curvature } & $-34.72--4.17$ & 9 & 170680 & -0.056 & 0.003 & -0.059 & 0.199 & 0.201 & 0.600 & 0.799 & 0.004 \\
\hline & $-4.17--1.39$ & 43 & 777064 & -0.008 & 0.002 & -0.010 & 0.209 & 0.201 & 0.590 & 0.799 & \\
\hline & $-1.39-0.88$ & 76 & 1299477 & 0.048 & -0.029 & 0.077 & 0.221 & 0.195 & 0.585 & 0.805 & \\
\hline
\end{tabular}
the degree of disbelief: Unc: the degree of uncertainly; Pls: the degree of plausibility. 
Table 3. Cont.

\begin{tabular}{|c|c|c|c|c|c|c|c|c|c|c|c|}
\hline Factors & Class & $\begin{array}{c}\text { No. of } \\
\text { Landslide }\end{array}$ & $\begin{array}{l}\text { No. of Pixels } \\
\text { in Domain }\end{array}$ & $\mathrm{W}^{+}$ & $\mathbf{W}^{-}$ & C & Bel & Dis & Unc & Pls & $\mathbf{w}_{\mathrm{j}}$ \\
\hline \multirow{4}{*}{ Slope angle $\left({ }^{\circ}\right)$} & $10-20$ & 84 & 1233686 & 0.200 & -0.128 & 0.328 & 0.168 & 0.110 & 0.722 & 0.890 & \\
\hline & $40-50$ & 11 & 186715 & 0.055 & -0.003 & 0.058 & 0.145 & 0.125 & 0.730 & 0.875 & \\
\hline & $50-60$ & 8 & 58411 & 0.899 & -0.025 & 0.924 & 0.337 & 0.122 & 0.541 & 0.878 & \\
\hline & $60-70$ & 0 & 8690 & 0.000 & 0.002 & 0.000 & 0.000 & 0.000 & 1.000 & 1.000 & \\
\hline \multirow{7}{*}{ Slope aspect } & North & 28 & 508458 & -0.013 & 0.002 & -0.015 & 0.124 & 0.111 & 0.764 & 0.889 & \\
\hline & Northeast & 33 & 489376 & 0.190 & -0.035 & 0.225 & 0.152 & 0.107 & 0.741 & 0.893 & \\
\hline & East & 26 & 507513 & -0.085 & 0.014 & -0.099 & 0.115 & 0.113 & 0.772 & 0.887 & \\
\hline & Southeast & 20 & 402282 & -0.115 & 0.014 & -0.129 & 0.112 & 0.113 & 0.775 & 0.887 & \\
\hline & South & 24 & 393289 & 0.090 & -0.012 & 0.102 & 0.138 & 0.110 & 0.753 & 0.890 & \\
\hline & Southwest & 16 & 351360 & -0.203 & 0.020 & -0.223 & 0.103 & 0.113 & 0.784 & 0.887 & \\
\hline & West & 20 & 414052 & -0.144 & 0.018 & -0.162 & 0.109 & 0.113 & 0.778 & 0.887 & \\
\hline Distance to roads (m) & $>2,000$ & 22 & 1197500 & -1.110 & 0.300 & -1.410 & 0.060 & 0.267 & 0.674 & 0.733 & \\
\hline \multirow[t]{5}{*}{ Distance to rivers $(\mathrm{m})$} & $0-200$ & 57 & 1032619 & -0.010 & 0.004 & -0.014 & 0.208 & 0.201 & 0.591 & 0.799 & 0.022 \\
\hline & 200-400 & 69 & 844083 & 0.382 & -0.160 & 0.543 & 0.308 & 0.171 & 0.521 & 0.829 & \\
\hline & $400-600$ & 29 & 700716 & -0.298 & 0.063 & -0.361 & 0.156 & 0.213 & 0.630 & 0.787 & \\
\hline & $600-800$ & 22 & 496233 & -0.229 & 0.033 & -0.263 & 0.167 & 0.207 & 0.626 & 0.793 & \\
\hline & $>800$ & 18 & 423048 & -0.271 & 0.032 & -0.303 & 0.160 & 0.207 & 0.633 & 0.793 & \\
\hline \multirow[t]{5}{*}{ TWI } & $0.35-1.63$ & 104 & 1318729 & 0.347 & -0.289 & 0.635 & 0.401 & 0.152 & 0.447 & 0.848 & 0.080 \\
\hline & $1.63-2.41$ & 66 & 1221212 & -0.031 & 0.016 & -0.048 & 0.275 & 0.206 & 0.519 & 0.794 & \\
\hline & $2.41-3.36$ & 20 & 653109 & -0.599 & 0.099 & -0.698 & 0.156 & 0.224 & 0.621 & 0.776 & \\
\hline & $3.36-4.81$ & 4 & 243618 & -1.223 & 0.051 & -1.274 & 0.083 & 0.213 & 0.703 & 0.787 & \\
\hline & $4.81-14.58$ & 1 & 60031 & -1.208 & 0.012 & -1.221 & 0.085 & 0.205 & 0.710 & 0.795 & \\
\hline \multirow[t]{3}{*}{ NDVI } & $-0.13-0.13$ & 2 & 110968 & -1.130 & 0.022 & -1.151 & 0.077 & 0.206 & 0.717 & 0.794 & 0.037 \\
\hline & $0.13-0.24$ & 15 & 350282 & -0.264 & 0.026 & -0.290 & 0.184 & 0.206 & 0.610 & 0.794 & \\
\hline & $0.24-0.30$ & 41 & 864378 & -0.162 & 0.048 & -0.210 & 0.204 & 0.211 & 0.585 & 0.789 & \\
\hline \multirow{9}{*}{ Soil } & Type 2 & 12 & 208103 & 0.033 & -0.002 & 0.036 & 0.154 & 0.099 & 0.747 & 0.901 & \\
\hline & Type 3 & 4 & 96481 & -0.296 & 0.007 & -0.304 & 0.111 & 0.100 & 0.789 & 0.900 & \\
\hline & Type 4 & 9 & 147720 & 0.088 & -0.004 & 0.093 & 0.163 & 0.099 & 0.738 & 0.901 & \\
\hline & Type 5 & 1 & 41304 & -0.834 & 0.007 & -0.841 & 0.065 & 0.100 & 0.835 & 0.900 & \\
\hline & Type 6 & 0 & 3783 & 0.000 & 0.001 & 0.000 & 0.000 & 0.000 & 1.000 & 1.000 & \\
\hline & Type 7 & 0 & 27855 & 0.000 & 0.008 & 0.000 & 0.000 & 0.000 & 1.000 & 1.000 & \\
\hline & Type 8 & 54 & 1441599 & -0.398 & 0.207 & -0.605 & 0.100 & 0.123 & 0.777 & 0.877 & \\
\hline & Type 9 & 0 & 68835 & 0.000 & 0.020 & 0.000 & 0.000 & 0.000 & 1.000 & 1.000 & \\
\hline & Type 10 & 84 & 1020437 & 0.389 & -0.218 & 0.608 & 0.220 & 0.080 & 0.700 & 0.920 & \\
\hline \multirow[t]{10}{*}{ Lithology } & A & 26 & 396261 & 0.163 & -0.023 & 0.185 & 0.159 & 0.098 & 0.743 & 0.902 & 0.141 \\
\hline & B & 43 & 424981 & 0.596 & -0.120 & 0.715 & 0.245 & 0.089 & 0.666 & 0.911 & \\
\hline & C & 59 & 765703 & 0.323 & -0.113 & 0.437 & 0.186 & 0.089 & 0.724 & 0.911 & \\
\hline & D & 17 & 252004 & 0.190 & -0.016 & 0.207 & 0.163 & 0.099 & 0.738 & 0.901 & \\
\hline & $\mathrm{E}$ & 38 & 686719 & -0.008 & 0.002 & -0.010 & 0.134 & 0.100 & 0.766 & 0.900 & \\
\hline & $\mathrm{F}$ & 1 & 267436 & -2.702 & 0.074 & -2.777 & 0.009 & 0.108 & 0.883 & 0.892 & \\
\hline & G & 10 & 467170 & -0.958 & 0.091 & -1.048 & 0.052 & 0.110 & 0.839 & 0.890 & \\
\hline & $\mathrm{H}$ & 0 & 97599 & 0.000 & 0.028 & 0.000 & 0.000 & 0.000 & 1.000 & 1.000 & \\
\hline & I & 1 & 46018 & -0.942 & 0.008 & -0.951 & 0.053 & 0.101 & 0.846 & 0.899 & \\
\hline & J & 0 & 92808 & 0.000 & 0.027 & 0.000 & 0.000 & 0.000 & 1.000 & 1.000 & \\
\hline
\end{tabular}

\subsection{Generating Landslide Susceptibility Maps}

Generating landslide susceptibility maps is the final output step after the processes of independence test of conditioning factors, establishing, training, and validation models, and it can be roughly divided into two steps [128]. The first step is acquiring the landslide susceptibility indexes (LSIs) of all evaluation units. The second is regrouping the LSIs. For the first step, the LSI of each evaluation unit was calculated by probability distribution functions of evaluation models. For the second step, the LSIs were reclassified into several intervals by standard classification methods in ArcGIS software. Table 4 shows the coefficient of landslide conditioning factor in each ensemble model. When the coefficient is greater than 0 , it indicates that the factor will promote the occurrence of landslide. On the contrary, a coefficient less than 0 means the factor will impede the occurrence of landslide. While 0 indicates the 
factor has no effect on the occurrence of landslide. It can be seen that only slope aspect impeded the occurrence of landslide and profile curvature performed best in the promotion factors, especially in IoE-LR model.

For the slope angle, landslides were most concentrate on the class $50^{\circ}-60^{\circ}$ which owned the Bel of 0.337 , indicating it has the highest probability of landslide occurrence, followed by the class $20^{\circ}-30^{\circ}$. For the land use, the Bel was highest for farm land (0.421) and lowest for grass land, water and bare land (they have the same Bel of 0). For the soil, the Bel was highest for the type of A (0.188). In the case of attitude, the Bel was 0.387 for the class $500-700 \mathrm{~m}$. In the case of lithology, the Bel was 0.245 for the type $B$, indicating landslides were more likely to occur in this lithological condition. For the TWI, the Bel was the highest for class 0.35-1.63. For the NDVI, the Bel was 0.286 for class $0.30-0.37$. For the slope aspect, the Bel was the highest for northeast slopes (0.152) and lowest for flat slopes (0.0). In the case of distance to roads and rivers, the Bel decreases when distance to a road or river line increases. In the case of plan and profile curvature, the most of landslides occurred in class $0.56-2.62$ and $-1.39-0.88$, respectively.

The process of LSI calculated by EBF model is illustrated as an example. As described above, Bel decides the LSI of EBF model, and the calculation equation is shown in Equation (19). Similarly, the equations for generating LSI of WoE and IoE models are shown in Equation (20) and Equation (21), respectively. In addition, the EBF-LR model is also illustrated as an example of ensemble models. Generally, the process of LSI produced by ensemble model can be roughly described as multiplying the coefficients of ensemble model by the weights obtained in bivariate statistical model. For example, the LSI of EBF-LR model was obtained by multiplying the coefficients of EBF-LR model and Bels generated by EBF model, as shown in Equation (22). Similarly, the equations for calculating LSI of WoE-LR and IoE-LR models are shown in Equation (23) and Equation (24), respectively. Finally, the natural break method was applied to reclassify the indexes into five classes, such as very low, low, moderate, high and very high, and the landslide susceptibility maps generated by EBF, WoE, IoE, EBF-LR, WoE-LR, and IoE-LR models are shown in Figure 3.

$$
\begin{aligned}
& \text { LSI }_{E B F}=\left(\text { Altitude }_{\text {Bel }}\right)+\left(\text { Plancurvature }_{\text {Bel }}\right)+\left(\text { Profilecurvature }_{\text {Bel }}\right)+ \\
& \left(\text { Slopeangle }_{B e l}\right)+\left(\text { Slopeaspect }_{B e l}\right)+\left(\text { Distancetoroads }_{B e l}\right)+ \\
& \left(\text { Distancetorivers }_{B e l}\right)+\left(\text { TWI }_{B e l}\right)+\left(N_{\text {DVI }} \text { Bel }\right)+\left(\text { Landuse }_{B e l}\right)+ \\
& \left(\text { Soil }_{\text {Bel }}\right)+\left(\text { lithology } y_{\text {Bel }}\right) \\
& \text { LSI }_{\text {WoE }}=\left(\text { Altitude }_{C}\right)+\left(\text { Plancurvature }_{C}\right)+\left(\text { Profilecurvature }_{C}\right)+ \\
& \left(\text { Slopeangle }_{C}\right)+\left(\text { Slopeaspect }_{C}\right)+\left(\text { Distancetoroads }_{C}\right)+ \\
& \left(\text { Distancetorivers }_{C}\right)+\left(\text { TWI }_{C}\right)+\left(\text { NDVI }_{C}\right)+\left(\text { Landuse }_{C}\right)+ \\
& \left(\text { Soil }_{C}\right)+\left(\text { litholog } y_{C}\right) \\
& \text { LSI IoE }_{\text {Ioltitude } * 0.190)}+(\text { Plancurvature } * 0.009)+ \\
& (\text { Profilecurvature } * 0.004)+(\text { Slopeangle } * 0.229)+ \\
& (\text { Slopeaspect } * 0.051)+(\text { Distancetoroads } * 0.062)+ \\
& (\text { Distancetorivers } * 0.022)+(T W I * 0.080)+(N D V I * 0.037)+ \\
& (\text { Landuse } * 0.207)+(\text { Soil } * 0.194)+(\text { litholog } y * 0.141) \\
& \text { LSI }_{E B F-L R}=\left(\text { Altitude }_{B e l} * 8.123\right)+\left(\text { Plancurvature }_{B e l} * 4.169\right)+ \\
& \text { (Profilecurvature } \left._{B e l} * 22.826\right)+\left(\text { Slopeangle }_{B e l} * 20.993\right)+ \\
& \left(\text { Slopeaspect }_{B e l} *(-17.300)\right)+\left(\text { Distancetoroads }_{B e l} * 2.634\right)+ \\
& \left(\text { Distancetorivers }_{B e l} * 5.298\right)+\left(\mathrm{TWI}_{\mathrm{Bel}} * 3.204\right)+\left(\mathrm{NDVI}_{\mathrm{Bel}} * 2.710\right)+ \\
& \left(\text { Landuse }_{B e l} * 1.560\right)+\left(\text { Soil }_{B e l} * 2.520\right)+\left(\text { lithology }_{B e l} * 3.951\right)
\end{aligned}
$$



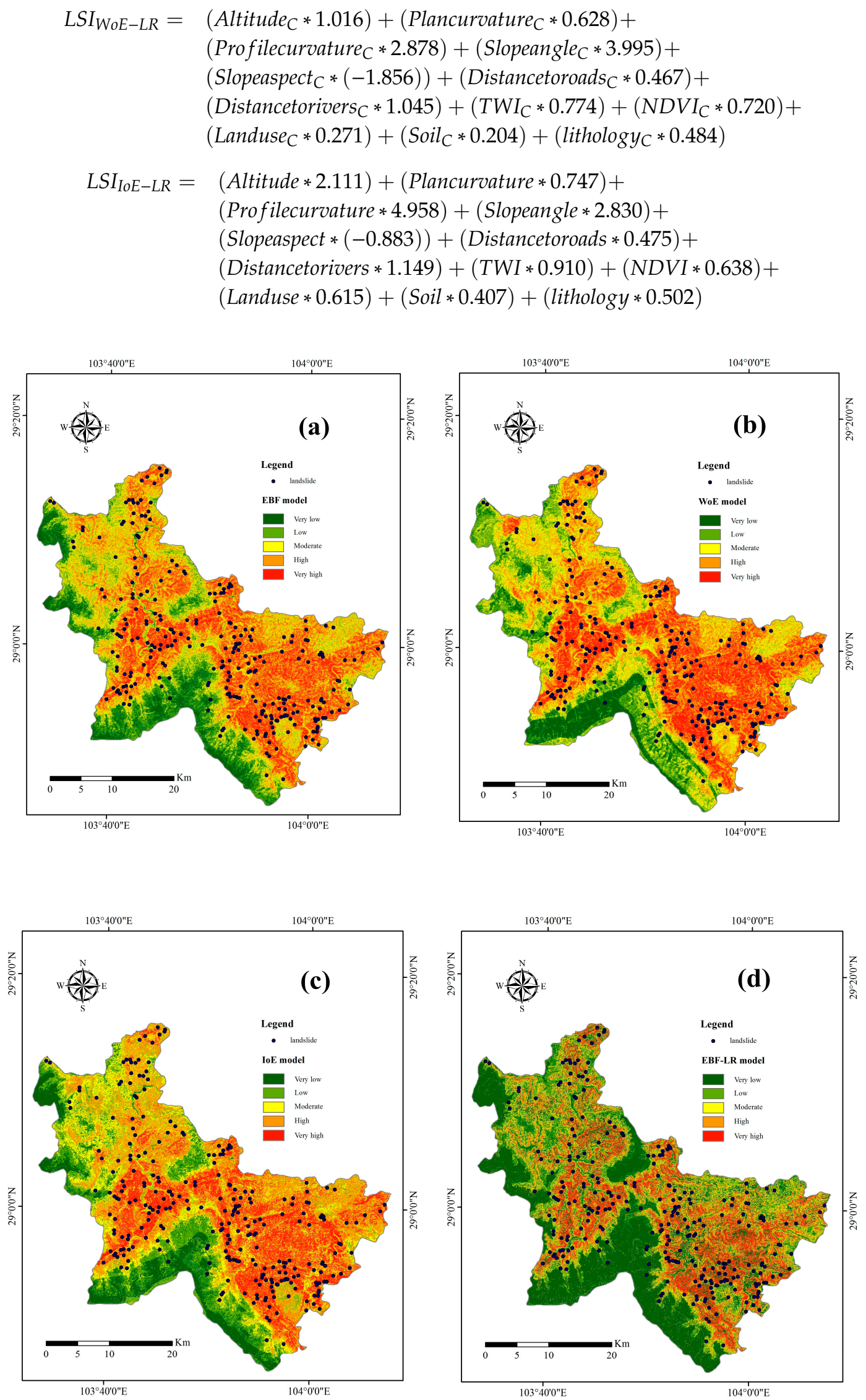

Figure 3. Cont. 

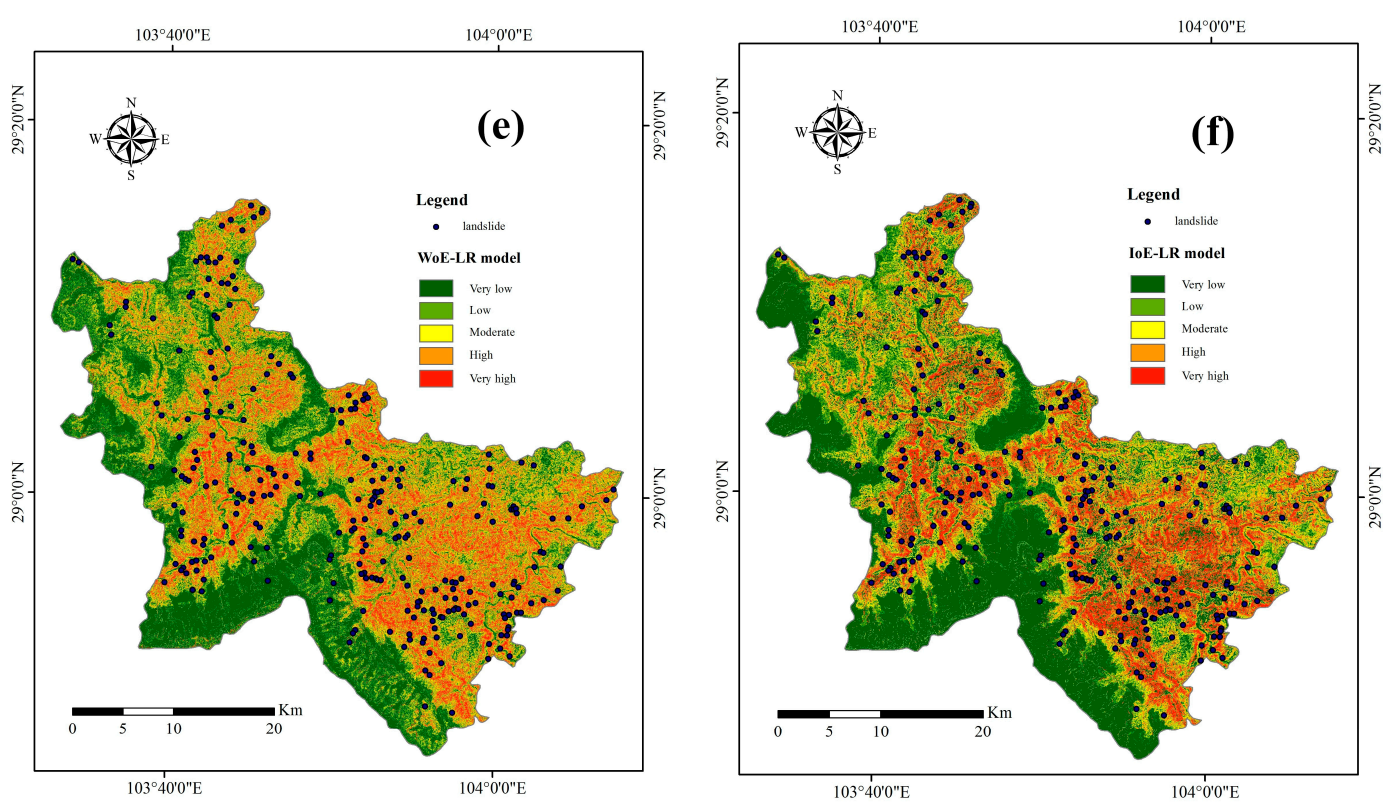

Figure 3. Landslide susceptibility maps: (a) EBF model; (b) WoE model; (c) IoE model; (d) EBF-LR model; (e) WoE-LR model; (f) IoE-LR model.

Table 4. The coefficients of evaluation models.

\begin{tabular}{cccc}
\hline Landslide Conditioning Factors & WoE-LR & EBF-LR & IoE-LR \\
\hline Slope aspect & 0.780 & 6.477 & 15.569 \\
Altitude & 1.016 & 8.123 & 11.110 \\
Land use & 0.271 & 1.560 & 2.973 \\
Lithology & 0.484 & 3.951 & 3.567 \\
NDVI & 0.720 & 2.710 & 17.231 \\
Plan curvature & 0.628 & 4.169 & 82.950 \\
Profile curvature & 2.878 & 22.826 & 1239.456 \\
Distance to rivers & 1.045 & 5.298 & 52.206 \\
Distance to roads & 0.467 & 2.634 & 7.665 \\
Slope angle & 3.995 & 20.993 & 12.357 \\
Soil & 0.204 & 2.520 & 2.100 \\
TWI & 0.774 & 3.204 & 11.377 \\
Slope aspect & -1.856 & -17.300 & -17.304 \\
\hline
\end{tabular}

\subsection{Model Validation and Comparison}

Model validation is an important part of landslide susceptibility research which determines the accuracy of the study $[26,129]$. The landslide susceptibility maps will have no practical significances without model validation [130]. In the first place, the Wilcoxon signed-rank test was introduced to test the independence of all evaluation models (Table 5). The 95\% confidence interval of Wilcoxon signed-rank test is $(-\propto,-1.96) \cup(1.96,+\infty)$. It can be seen form the Table 5 that all the evaluation models are independent from each other. Then, the receiver operating characteristic (ROC) curve was applied to assess the predictive ability of those models. The ROC curve is a widely-used statistical approach as it has the ability to evaluate the prediction accuracy of models quantitatively. The area under the ROC curve (AUC) shows the performances of landslide susceptibility evaluation models in this paper. Figure 4 represents the ROC curves of evaluation models and Table 6 shows the parameters of ROC curves. It can be seen that EBF-LR model has the highest accuracy (0.826), followed by IoE-LR model (0.825), WoE-LR model (0.792), EBF model (0.791), IoE model (0.778), and WoE model (0.753). The other statistical methods show the similar results, such as EBF-LR model has the smallest standard error (SE) and $95 \%$ confidence interval $(\mathrm{CI})$. 
Table 5. Wilcoxon signed-rank test for evaluation models.

\begin{tabular}{ccccccccc}
\hline Model & M1 & M2 & M3 & M4 & M5 & M6 & M7 & M8 \\
\hline Z & -12.651 & -12.968 & -14.119 & -15.345 & -13.752 & -15.018 & -15.077 & -16.006 \\
Asymp. Sig. (2-tailed) & 0 & 0 & 0 & 0 & 0 & 0 & 0 & 0 \\
Model & M9 & M10 & M11 & M12 & M13 & M14 & M15 & \\
Z & -14.900 & -10.849 & -12.203 & -10.313 & -2.577 & -4.809 & -3.680 & \\
Asymp. Sig. (2-tailed) & 0 & 0 & 0 & 0 & 0 & 0 & 0 & \\
\hline
\end{tabular}

M1: WoE-EBF, M2: IoE-EBF, M3: EBF_LR-EBF, M4: WoE_LR-EBF, M5: IoE_LR-EBF, M6: IoE-WoE, M7: EBF_LR-WoE, M8: WoE_LR-WoE, M9: IoE_LR-WoE, M10: EBF_LR-IoE, M11: WoE_LR-IoE, M12: IoE_LR-IoE, M13: WoE_LR-EBF_LR, M14: IoE_LR-EBF_LR, M15: IoE_LR-WoE_LR.

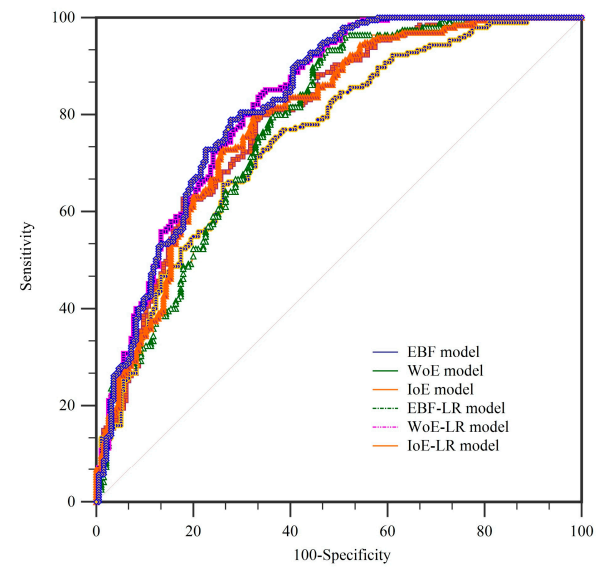

Figure 4. Receiver operating characteristic (ROC) curves using validation dataset.

Table 6. ROC curves. AUC: Area under curve; SE: standard error; CI: confidence interval.

\begin{tabular}{cccc}
\hline Variables & AUC & SE & 95\% CI \\
\hline EBF model & 0.791 & 0.0226 & 0.747 to 0.830 \\
WoE model & 0.753 & 0.0243 & 0.707 to 0.795 \\
IoE model & 0.778 & 0.0233 & 0.734 to 0.819 \\
EBF-LR model & 0.826 & 0.0207 & 0.784 to 0.862 \\
WoE-LR model & 0.792 & 0.0226 & 0.748 to 0.831 \\
IoE-LR model & 0.825 & 0.0208 & 0.784 to 0.861 \\
\hline
\end{tabular}

\section{Discussions}

Landslide is a kind of extremely dangerous geological disasters which has a significant influence on personal safety as well as property security and geological environment [131,132]. In this paper, based on LR model, three bivariate statistical models, namely EBF, WoE, and IoE models, were introduced to carry out the landslide susceptibility mapping in Muchuan County. The performances of those models were compared and validated by some statistical methods, such as ROC curve. Although those four models and their ensembles have been applied to landslide susceptibility mapping many times in recent years, they have the advantages of high accuracy and convenient operation. Althuwaynee et al. proposed a Geographic Information Systems (GIS)-based EBF model for data analysis and conducting the landslide susceptibility research in Kuala Lumpur city, Malaysia. They indicated that the prediction accuracy of EBF model is acceptable and landslide susceptibility map produced by it is trustworthy [38]. Wang et al. applied WoE model to landslide susceptibility mapping at Daguan County, Yunnan Province, China. The results believed that the method not only provided a reliable and easily interpreted result, but also simplified the modeling process and greatly improved the work efficiency [114]. Devkote et al. carried out the landslide susceptibility maps by IoE, LR, and certainty factor (CF) models at Mugling-Narayanghat road section, Nepal. After the validation and comparison processes, IoE model gained the highest AUC value, followed by LR and CF models [133]. As for the ensemble models, 
Chen et al. conducted a series of related studies and they reached the same conclusion as in this paper that the ensemble model obtained higher accuracy than their single models $[58,130,134]$. In the present study, a total of 279 landslides were identified and mapped in the landslide inventory map, of which $195(70 \%)$ landslides were randomly selected to establish the landslide models and the rest of the 84 $(30 \%)$ landslides were used to validate the veracity of models. As there are no general rules for selecting landslide conditioning factors, twelve factors such as altitude, plan curvature, profile curvature, slope angle, distance to roads, distance to rivers, TWI, NDVI, land use, soil, and lithology were prepared for the research according to the previous studies and local geological environment characteristics.

After the selection of landslide conditioning factors, all the factors were subjected to multicollinearity analysis so as to avoid the influences brought by linear factors. It can be seen from Table 2 that all the factors are independent from each other. $W^{+}$and $W^{-}$produced by WoE model are a pair of weight parameters that named positive weight and negative weight. A positive weight means it may promote the occurrence of landslide, while negative weight means the opposite. The parameter of Bel generated by EBF model can be regard as the symbol that indicates the relationship between landslide and landslide conditioning factor. The parameter of $W_{j}$ generated by IoE model represents the importance of each factor. It can be seen from the Table 3 that slope angle has the highest weight (0.229) which means it is the most important factor, followed by land use (0.207), soil (0.194), altitude (0.190), lithology (0.141), TWI (0.08), distance to roads (0.062), slope aspect (0.051), NDVI (0.037), distance to rivers (0.022), plan curvature (0.009), and profile curvature (0.004). In addition, it is obvious to find that Bel and $W^{+}$show the same results.

It can be seen from Figure 3 that the south and west sides of all the landslide susceptibility maps have the low and very low landslide susceptibility. From the parameter layers, it can be concluded that both the south and west sides have four similar characteristics, such as high altitude, far from the roads, high ratio of vegetation coverage and land use type is forest land. This may be the presence of cliffs with rock which is hard to weathering in high-altitude areas $[133,135,136]$. Besides, far from the roads means it is less affected by human activities $[137,138]$. In addition, high ratio of vegetation coverage and forest land indicates the vegetation growth status in this area is good. In other words, the better the growth status of vegetation, the lower the possibility of landslide occurrence [139-141].

The ROC curve, SE, and 95\% CI were introduced to validate and compare the performances of evaluation models. According to the parameters of ROC curves, EBF-LR model performed best with the AUC value of 0.826 , followed by IoE-LR, WoE-LR, EBF, IoE, and WoE models with the AUC values of $0.825,0.792,0.791,0.778$, and 0.753 , respectively. Generally, all the models performed well in this study. Based on the LR model, combined with EBF, WoE and IoE models, the landslide susceptibility of Muchuan County was researched successfully. Last but not least, the models used in this study are worthwhile to apply in other areas where have the same geological environment characteristics as study area and the results obtained in this study can provide references for local government.

\section{Conclusions}

In this case research, WoE, EBF, IoE, and LR models were introduced to generate the landslide susceptibility maps for the Muchuan County, China. A total of 279 landslides were identified and mapped through the field investigation and interpretation of aerial photographs. The models were established by randomly selected $70 \%$ of the landslides and validated by the remaining landslides. The correlation between landslide occurrence and 12 landslide conditioning factors such as altitude, plan curvature, profile curvature, slope angle, distance to roads, distance to rivers, TWI, NDVI, land use, soil, and lithology was evaluated by the above models. Finally, six landslide susceptibility maps were classified into five classes, such as very low, low, moderate, high, and very high, by natural break method. The differences of spatial prediction ability of different models are compared by AUC values and the validation results indicate the EBF-LR model has the highest AUC value (0.826), which means EBF-LR model performed best in this research, followed by IoE-LR, WoE-LR, EBF, IoE and WoE models with the AUC values of $0.825,0.792$, 
$0.791,0.778$, and 0.753 , respectively. Finally, those landslide susceptibility maps can provide references of landslide prevention and land use planning for local government.

Author Contributions: R.L. and N.W. contributed equally to the work. R.L. collected field data, conducted the landslide mapping and wrote the manuscript. N.W. provided critical comments in planning this paper and edited the manuscript. Both the authors discussed the results and edited the manuscript.

Acknowledgments: The authors would like to thank the editorial comments and anonymous reviewers for their comments during the paper review process. This study was supported by the National Natural Science Foundation of China (Grant No. 41572287) and Science \& Technology Co-ordination and Innovation Projection of Shaanxi Province (Grant No. 2016KTCL03-19). Last but not least, sincere gratitude should also be sent to Min Luo, a girl who helped R.L. a lot in recent time and has captured his heart.

Conflicts of Interest: No potential conflict of interest was reported by the authors.

\section{References}

1. Grahn, T.; Jaldell, H. Assessment of data availability for the development of landslide fatality curves. Landslides 2017, 14, 1113-1126. [CrossRef]

2. Huang, F.; Chen, L.; Yin, K.; Huang, J.; Gui, L. Object-oriented change detection and damage assessment using high-resolution remote sensing images, Tangjiao Landslide, Three Gorges Reservoir, China. Environ. Earth Sci. 2018, 77, 183. [CrossRef]

3. Petrucci, O.; Gullà, G. A simplified method for assessing landslide damage indices. Nat. Hazards 2010, 52, 539-560. [CrossRef]

4. Hung, L.Q.; Van, N.T.H.; Duc, D.M.; Ha, L.T.C.; Van Son, P.; Khanh, N.H.; Binh, L.T. Landslide susceptibility mapping by combining the analytical hierarchy process and weighted linear combination methods: A case study in the upper Lo River catchment (Vietnam). Landslides 2016, 13, 1285-1301. [CrossRef]

5. Neuhäuser, B.; Damm, B.; Terhorst, B. GIS-based assessment of landslide susceptibility on the base of the Weights-of-Evidence model. Landslides 2012, 9, 511-528. [CrossRef]

6. Chen, W.; Li, H.; Hou, E.; Wang, S.; Wang, G.; Panahi, M.; Li, T.; Peng, T.; Guo, C.; Niu, C.; et al. GIS-based groundwater potential analysis using novel ensemble weights-of-evidence with logistic regression and functional tree models. Sci. Total Environ. 2018, 634, 853-867. [CrossRef] [PubMed]

7. Hong, H.; Pradhan, B.; Xu, C.; Tien Bui, D. Spatial prediction of landslide hazard at the Yihuang area (China) using two-class kernel logistic regression, alternating decision tree and support vector machines. CATENA 2015, 133, 266-281. [CrossRef]

8. Jebur, M.N.; Pradhan, B.; Tehrany, M.S. Optimization of landslide conditioning factors using very high-resolution airborne laser scanning (LiDAR) data at catchment scale. Remote Sens. Environ. 2014, 152, 150-165. [CrossRef]

9. Peng, J.; Wang, S.; Wang, Q.; Zhuang, J.; Huang, W.; Zhu, X.; Leng, Y.; Ma, P. Distribution and genetic types of loess landslides in China. J. Asian Earth Sci. 2019, 170, 329-350. [CrossRef]

10. Broeckx, J.; Vanmaercke, M.; Duchateau, R.; Poesen, J. A data-based landslide susceptibility map of Africa. Earth Sci. Rev. 2018, 185, 102-121. [CrossRef]

11. Guzzetti, F.; Mondini, A.C.; Cardinali, M.; Fiorucci, F.; Santangelo, M.; Chang, K.-T. Landslide inventory maps: New tools for an old problem. Earth Sci. Rev. 2012, 112, 42-66. [CrossRef]

12. Li, H.; Xu, Q.; He, Y.; Deng, J. Prediction of landslide displacement with an ensemble-based extreme learning machine and copula models. Landslides 2018, 15, 2047-2059. [CrossRef]

13. Frattini, P.; Crosta, G.; Carrara, A. Techniques for evaluating the performance of landslide susceptibility models. Eng. Geol. 2010, 111, 62-72. [CrossRef]

14. Yoshimatsu, H.; Abe, S. A review of landslide hazards in Japan and assessment of their susceptibility using an analytical hierarchic process (AHP) method. Landslides 2006, 3, 149-158. [CrossRef]

15. Mondal, S.; Maiti, R. Integrating the Analytical Hierarchy Process (AHP) and the frequency ratio (FR) model in landslide susceptibility mapping of Shiv-khola watershed, Darjeeling Himalaya. Int. J. Disaster Risk Sci. 2013, 4, 200-212. [CrossRef]

16. Myronidis, D.; Papageorgiou, C.; Theophanous, S. Landslide susceptibility mapping based on landslide history and analytic hierarchy process (AHP). Nat. Hazards 2016, 81, 245-263. [CrossRef] 
17. Quan, H.-C.; Lee, B.-G. GIS-based landslide susceptibility mapping using analytic hierarchy process and artificial neural network in Jeju (Korea). KSCE J. Civil Eng. 2012, 16, 1258-1266. [CrossRef]

18. Wang, Q.; Li, W.; Xing, M.; Wu, Y.; Pei, Y.; Yang, D.; Bai, H. Landslide susceptibility mapping at Gongliu county, China using artificial neural network and weight of evidence models. Geosci. J. 2016, 20, 705-718. [CrossRef]

19. Zare, M.; Pourghasemi, H.R.; Vafakhah, M.; Pradhan, B. Landslide susceptibility mapping at Vaz Watershed (Iran) using an artificial neural network model: A comparison between multilayer perceptron (MLP) and radial basic function (RBF) algorithms. Arab. J. Geosci. 2013, 6, 2873-2888. [CrossRef]

20. Feizizadeh, B.; Roodposhti, M.S.; Blaschke, T.; Aryal, J. Comparing GIS-based support vector machine kernel functions for landslide susceptibility mapping. Arab. J. Geosci. 2017, 10, 122. [CrossRef]

21. Pourghasemi, H.R.; Jirandeh, A.G.; Pradhan, B.; Xu, C.; Gokceoglu, C. Landslide susceptibility mapping using support vector machine and GIS at the Golestan Province, Iran. J. Earth Syst. Sci. 2013, 122, 349-369. [CrossRef]

22. Wu, X.; Ren, F.; Niu, R. Landslide susceptibility assessment using object mapping units, decision tree, and support vector machine models in the Three Gorges of China. Environ. Earth Sci. 2014, 71, 4725-4738. [CrossRef]

23. Chen, W.; Zhao, X.; Shahabi, H.; Shirzadi, A.; Khosravi, K.; Chai, H.; Zhang, S.; Zhang, L.; Ma, J.; Chen, Y.; et al. Spatial prediction of landslide susceptibility by combining evidential belief function, logistic regression and logistic model tree. Geocarto Int. 2019. [CrossRef]

24. Tien Bui, D.; Tuan, T.A.; Klempe, H.; Pradhan, B.; Revhaug, I. Spatial prediction models for shallow landslide hazards: A comparative assessment of the efficacy of support vector machines, artificial neural networks, kernel logistic regression, and logistic model tree. Landslides 2016, 13, 361-378. [CrossRef]

25. Chen, W.; Shirzadi, A.; Shahabi, H.; Ahmad, B.B.; Zhang, S.; Hong, H.; Zhang, N. A novel hybrid artificial intelligence approach based on the rotation forest ensemble and naïve Bayes tree classifiers for a landslide susceptibility assessment in Langao County, China. Geomat. Nat. Hazards Risk 2017, 8, 1955-1977. [CrossRef]

26. Hong, H.; Liu, J.; Bui, D.T.; Pradhan, B.; Acharya, T.D.; Pham, B.T.; Zhu, A.X.; Chen, W.; Ahmad, B.B. Landslide susceptibility mapping using J48 Decision Tree with AdaBoost, Bagging and Rotation Forest ensembles in the Guangchang area (China). CATENA 2018, 163, 399-413. [CrossRef]

27. Pham, B.T.; Tien Bui, D.; Prakash, I. Application of Classification and Regression Trees for Spatial Prediction of Rainfall-Induced Shallow Landslides in the Uttarakhand Area (India) Using GIS. In Climate Change, Extreme Events and Disaster Risk Reduction: Towards Sustainable Development Goals; Mal, S., Singh, R.B., Huggel, C., Eds.; Springer International Publishing: Cham, Switzerland, 2018; pp. 159-170.

28. Sahana, M.; Sajjad, H. Evaluating effectiveness of frequency ratio, fuzzy logic and logistic regression models in assessing landslide susceptibility: A case from Rudraprayag district, India. J. Mt. Sci. 2017, 14, 2150-2167. [CrossRef]

29. Aghdam, I.N.; Varzandeh, M.H.M.; Pradhan, B. Landslide susceptibility mapping using an ensemble statistical index (Wi) and adaptive neuro-fuzzy inference system (ANFIS) model at Alborz Mountains (Iran). Environ. Earth Sci. 2016, 75, 553. [CrossRef]

30. Chen, W.; Panahi, M.; Khosravi, K.; Pourghasemi, H.R.; Rezaie, F.; Parvinnezhad, D. Spatial prediction of groundwater potentiality using ANFIS ensembled with teaching-learning-based and biogeography-based optimization. J. Hydrol. 2019, 572, 435-448. [CrossRef]

31. Bui, D.T.; Tsangaratos, P.; Ngo, P.-T.T.; Pham, T.D.; Pham, B.T. Flash flood susceptibility modeling using an optimized fuzzy rule based feature selection technique and tree based ensemble methods. Sci. Total Environ. 2019, 668, 1038-1054. [CrossRef]

32. Chen, W.; Tsangaratos, P.; Ilia, I.; Duan, Z.; Chen, X. Groundwater spring potential mapping using population-based evolutionary algorithms and data mining methods. Sci. Total Environ. 2019, 684, 31-49. [CrossRef] [PubMed]

33. Rossi, M.; Luciani, S.; Valigi, D.; Kirschbaum, D.; Brunetti, M.T.; Peruccacci, S.; Guzzetti, F. Statistical approaches for the definition of landslide rainfall thresholds and their uncertainty using rain gauge and satellite data. Geomorphology 2017, 285, 16-27. [CrossRef]

34. Schicker, R.; Moon, V. Comparison of bivariate and multivariate statistical approaches in landslide susceptibility mapping at a regional scale. Geomorphology 2012, 161, 40-57. [CrossRef] 
35. Lee, S.; Pradhan, B. Landslide hazard mapping at Selangor, Malaysia using frequency ratio and logistic regression models. Landslides 2007, 4, 33-41. [CrossRef]

36. Pradhan, B.; Lee, S. Delineation of landslide hazard areas on Penang Island, Malaysia, by using frequency ratio, logistic regression, and artificial neural network models. Environ. Earth Sci. 2010, 60, 1037-1054. [CrossRef]

37. Sharma, S.; Mahajan, A.K. A comparative assessment of information value, frequency ratio and analytical hierarchy process models for landslide susceptibility mapping of a Himalayan watershed, India. Bull. Eng. Geol. Environ. 2018. [CrossRef]

38. Althuwaynee, O.F.; Pradhan, B.; Lee, S. Application of an evidential belief function model in landslide susceptibility mapping. Comput. Geosci. 2012, 44, 120-135. [CrossRef]

39. Gayen, A.; Saha, S. Application of weights-of-evidence (WoE) and evidential belief function (EBF) models for the delineation of soil erosion vulnerable zones: A study on Pathro river basin, Jharkhand, India. Model. Earth Syst. Environ. 2017, 3, 1123-1139. [CrossRef]

40. Chen, W.; Shahabi, H.; Shirzadi, A.; Hong, H.; Akgun, A.; Tian, Y.; Liu, J.; Zhu, A.X.; Li, S. Novel hybrid artificial intelligence approach of bivariate statistical-methods-based kernel logistic regression classifier for landslide susceptibility modeling. Bull. Eng. Geol. Environ. 2018. [CrossRef]

41. Goetz, J.N.; Brenning, A.; Petschko, H.; Leopold, P. Evaluating machine learning and statistical prediction techniques for landslide susceptibility modeling. Comput. Geosci. 2015, 81, 1-11. [CrossRef]

42. Fan, W.; Wei, X.S.; Cao, Y.B.; Zheng, B. Landslide susceptibility assessment using the certainty factor and analytic hierarchy process. J. Mt. Sci. 2017, 14, 906-925. [CrossRef]

43. Pradhan, B.; Sameen, M.I. Landslide Susceptibility Modeling: Optimization and Factor Effect Analysis. In Laser Scanning Applications in Landslide Assessment; Pradhan, B., Ed.; Springer International Publishing: Cham, Switzerland, 2017; pp. 115-132.

44. Mandal, S.P.; Chakrabarty, A.; Maity, P. Comparative evaluation of information value and frequency ratio in landslide susceptibility analysis along national highways of Sikkim Himalaya. Spat. Inf. Res. 2018, 26, 127-141. [CrossRef]

45. Sarkar, S.; Roy, A.K.; Martha, T.R. Landslide susceptibility assessment using Information Value Method in parts of the Darjeeling Himalayas. J. Geol. Soc. India 2013, 82, 351-362. [CrossRef]

46. Borrelli, L.; Ciurleo, M.; Gullà, G. Correction to: Shallow landslide susceptibility assessment in granitic rocks using GIS-based statistical methods: The contribution of the weathering grade map. Landslides 2018, 15, 1143-1144. [CrossRef]

47. Hong, H.; Pourghasemi, H.R.; Pourtaghi, Z.S. Landslide susceptibility assessment in Lianhua County (China): A comparison between a random forest data mining technique and bivariate and multivariate statistical models. Geomorphology 2016, 259, 105-118. [CrossRef]

48. Mezaal, M.R.; Pradhan, B. An improved algorithm for identifying shallow and deep-seated landslides in dense tropical forest from airborne laser scanning data. CATENA 2018, 167, 147-159. [CrossRef]

49. Geospatial Data Cloud of Chinese Academy of Sciences (GSCloud). Digital elevation model; Geospatial Data Cloud of Chinese Academy of Sciences: Beijing, China, 2019.

50. Institute of Soil Science, Chinese Academy of Sciences (ISSCAS). Soil map; Institute of Soil Science, Chinese Academy of Sciences: Nanjing, China, 2019.

51. National Geological Archives of China (NGAC). Lithology map; National Geological Archives of China: Beijing, China, 2019.

52. Environmental Systems Research Institude (ESRI). ArcGIS Desktop: Release 10.0; Environmental Systems Research Institude: Redlands, CA, USA, 2010.

53. Pradhan, B.; Lee, S. Landslide susceptibility assessment and factor effect analysis: Backpropagation artificial neural networks and their comparison with frequency ratio and bivariate logistic regression modelling. Environ. Model. Softw. 2010, 25, 747-759. [CrossRef]

54. Sheng, T.; Chen, Q. An Altitude Based Landslide and Debris Flow Detection Method for a Single Mountain Remote Sensing Image. In Proceedings of the International Conference on Image and Graphics, Shanghai, China, 13-15 September 2017; Springer: Cham, Switzerland, 2017; pp. 601-610.

55. Zhou, C.; Yin, K.; Cao, Y.; Ahmed, B.; Li, Y.; Catani, F.; Pourghasemi, H.R. Landslide susceptibility modeling applying machine learning methods: A case study from Longju in the Three Gorges Reservoir area, China. Comput. Geosci. 2018, 112, 23-37. [CrossRef] 
56. Kornejady, A.; Pourghasemi, H.R.; Afzali, S.F. Presentation of RFFR New Ensemble Model for Landslide Susceptibility Assessment in Iran. In Landslides: Theory, Practice and Modelling; Pradhan, S.P., Vishal, V., Singh, T.N., Eds.; Springer International Publishing: Cham, Switzerland, 2019; pp. 123-143.

57. Samia, J.; Temme, A.; Bregt, A.; Wallinga, J.; Guzzetti, F.; Ardizzone, F.; Rossi, M. Characterization and quantification of path dependency in landslide susceptibility. Geomorphology 2017, 292, 16-24. [CrossRef]

58. Jacobs, L.; Dewitte, O.; Poesen, J.; Maes, J.; Mertens, K.; Sekajugo, J.; Kervyn, M. Landslide characteristics and spatial distribution in the Rwenzori Mountains, Uganda. J. Afr. Earth Sci. 2017, 134, 917-930. [CrossRef]

59. Pham, B.T.; Tien Bui, D.; Prakash, I. Bagging based Support Vector Machines for spatial prediction of landslides. Environ. Earth Sci. 2018, 77, 146. [CrossRef]

60. Zhuang, J.; Peng, J.; Wang, G.; Javed, I.; Wang, Y.; Li, W. Distribution and characteristics of landslide in Loess Plateau: A case study in Shaanxi province. Eng. Geol. 2018, 236, 89-96. [CrossRef]

61. Chen, W.; Panahi, M.; Tsangaratos, P.; Shahabi, H.; Ilia, I.; Panahi, S.; Li, S.; Jaafari, A.; Ahmad, B.B. Applying population-based evolutionary algorithms and a neuro-fuzzy system for modeling landslide susceptibility. CATENA 2019, 172, 212-231. [CrossRef]

62. Chen, W.; Pourghasemi, H.R.; Kornejady, A.; Xie, X. GIS-Based Landslide Susceptibility Evaluation Using Certainty Factor and Index of Entropy Ensembled with Alternating Decision Tree Models. In Natural Hazards GIS-Based Spatial Modeling Using Data Mining Techniques; Pourghasemi, H.R., Rossi, M., Eds.; Springer International Publishing: Cham, Switzerland, 2019; pp. 225-251.

63. Xie, J.; Uchimura, T.; Chen, P.; Liu, J.; Xie, C.; Shen, Q. A relationship between displacement and tilting angle of the slope surface in shallow landslides. Landslides 2019, 16, 1243-1251. [CrossRef]

64. Braun, A.; Garcia Urquia, E.L.; Moncada Lopez, R.; Yamagishi, H. Landslide Susceptibility Mapping in Tegucigalpa, Honduras, Using Data Mining Methods. In Proceedings of the IAEG/AEG Annual Meeting Proceedings, San Francisco, CA, USA, 17-21 September 2018; Springer International Publishing: Cham, Switzerland, 2019; Volume 1, pp. 207-215.

65. Can, A.; Dagdelenler, G.; Ercanoglu, M.; Sonmez, H. Landslide susceptibility mapping at Ovacık-Karabük (Turkey) using different artificial neural network models: Comparison of training algorithms. Bull. Eng. Geol. Environ. 2019, 78, 89-102. [CrossRef]

66. Wang, F.; Xu, P.; Wang, C.; Wang, N.; Jiang, N. Application of a GIS-Based Slope Unit Method for Landslide Susceptibility Mapping along the Longzi River, Southeastern Tibetan Plateau, China. ISPRS Int. J. Geo-Inf. 2017, 6, 172. [CrossRef]

67. Camilo, D.C.; Lombardo, L.; Mai, P.M.; Dou, J.; Huser, R. Handling high predictor dimensionality in slope-unit-based landslide susceptibility models through LASSO-penalized Generalized Linear Model. Environ. Model. Softw. 2017, 97, 145-156. [CrossRef]

68. Dou, J.; Yamagishi, H.; Pourghasemi, H.R.; Yunus, A.P.; Song, X.; Xu, Y.; Zhu, Z. An integrated artificial neural network model for the landslide susceptibility assessment of Osado Island, Japan. Nat. Hazards 2015, 78, 1749-1776. [CrossRef]

69. Arnold, P.; Dorren, L. The Importance of Rockfall and Landslide Risks on Swiss National Roads. In Proceedings of the Engineering Geology for Society and Territory Torino, Basel, Italy, 15-19 September 2014; Springer: Cham, Switzerland, 2015; Volume 6, pp. 671-675.

70. Dang, V.-H.; Dieu, T.B.; Tran, X.-L.; Hoang, N.-D. Enhancing the accuracy of rainfall-induced landslide prediction along mountain roads with a GIS-based random forest classifier. Bull. Eng. Geol. Environ. 2019, 78, 2835-2849. [CrossRef]

71. Losasso, L.; Rinaldi, C.; Alberico, D.; Sdao, F. Landslide Risk Analysis Along Strategic Touristic Roads in Basilicata (Southern Italy) Using the Modified RHRS 2.0 Method. In Proceedings of the Computational Science and Its Applications (ICCSA 2017), Trieste, Italy, 3-6 July 2017; Springer: Cham, Switzerland, 2017; pp. 761-776.

72. Sridhar, B.; Rao, P.J.; Narasimha Rao, G.; Duvvuru, R.; Anusha, C.; Sanyasi Naidu, D.; Srinivas, E.; Sridevi, T.; Madhuri, M.; Padmini, Y. Identification of Landslide Hazard Zones Along the Bheemili Beach Road, Visakhapatnam District, A.P. In Proceedings of International Conference on Remote Sensing for Disaster Management; Springer: Cham, Switzerland, 2019; pp. 515-522.

73. Cordeira, J.M.; Stock, J.; Dettinger, M.D.; Young, A.M.; Kalansky, J.F.; Ralph, F.M. A 142-year Climatology of Northern California Landslides and Atmospheric Rivers. Bull. Am. Meteorol. Soc. 2019. [CrossRef] 
74. Croissant, T.; Lague, D.; Steer, P.; Davy, P. Rapid post-seismic landslide evacuation boosted by dynamic river width. Nat. Geosci. 2017, 10, 680. [CrossRef]

75. Göransson, G.; Norrman, J.; Larson, M. Contaminated landslide runout deposits in rivers-Method for estimating long-term ecological risks. Sci. Total Environ. 2018, 642, 553-566. [CrossRef] [PubMed]

76. Zhao, T.; Dai, F.; Xu, N.-W. Coupled DEM-CFD investigation on the formation of landslide dams in narrow rivers. Landslides 2017, 14, 189-201. [CrossRef]

77. Canoglu, M.C.; Aksoy, H.; Ercanoglu, M. Integrated approach for determining spatio-temporal variations in the hydrodynamic factors as a contributing parameter in landslide susceptibility assessments. Bull. Eng. Geol. Environ. 2018. [CrossRef]

78. Chen, W.; Hong, H.; Li, S.; Shahabi, H.; Wang, Y.; Wang, X.; Ahmad, B.B. Flood susceptibility modelling using novel hybrid approach of reduced-error pruning trees with bagging and random subspace ensembles. J. Hydrol. 2019, 575, 864-873. [CrossRef]

79. Razavizadeh, S.; Solaimani, K.; Massironi, M.; Kavian, A. Mapping landslide susceptibility with frequency ratio, statistical index, and weights of evidence models: A case study in northern Iran. Environ. Earth Sci. 2017, 76, 499. [CrossRef]

80. Chen, C.-W.; Chen, H.; Oguchi, T. Distributions of landslides, vegetation, and related sediment yields during typhoon events in northwestern Taiwan. Geomorphology 2016, 273, 1-13. [CrossRef]

81. Fiorucci, F.; Ardizzone, F.; Mondini, A.C.; Viero, A.; Guzzetti, F. Visual interpretation of stereoscopic NDVI satellite images to map rainfall-induced landslides. Landslides 2019, 16, 165-174. [CrossRef]

82. Sun, W.; Tian, Y.; Mu, X.; Zhai, J.; Gao, P.; Zhao, G. Loess Landslide Inventory Map Based on GF-1 Satellite Imagery. Remote Sens. 2017, 9, 314. [CrossRef]

83. Bartelletti, C.; Giannecchini, R.; D’Amato Avanzi, G.; Galanti, Y.; Mazzali, A. The influence of geological-morphological and land use settings on shallow landslides in the Pogliaschina T. basin (northern Apennines, Italy). J. Maps 2017, 13, 142-152. [CrossRef]

84. Diva, I.H.; Irwanto, U.; Nizam, K.; Annur, L.; Sekarjati, D.; Putra, B.G.; Safitri, Y.; Giovandi, E.A.; Nofrizal, A.Y.; Hanif, M.; et al. Investigation Volcanic Land Form and Mapping Landslide Potential at Mount Talang. Sumatra J. Disaster Geogr. Geogr. Educ. 2018, 2, 16-23. [CrossRef]

85. Persichillo, M.G.; Bordoni, M.; Meisina, C. The role of land use changes in the distribution of shallow landslides. Sci. Total Environ. 2017, 574, 924-937. [CrossRef] [PubMed]

86. Basher, L.; Betts, H.; Lynn, I.; Marden, M.; McNeill, S.; Page, M.; Rosser, B. A preliminary assessment of the impact of landslide, earthflow, and gully erosion on soil carbon stocks in New Zealand. Geomorphology 2018, 307, 93-106. [CrossRef]

87. Cheng, C.-H.; Hsiao, S.-C.; Huang, Y.-S.; Hung, C.-Y.; Pai, C.-W.; Chen, C.-P.; Menyailo, O.V. Landslide-induced changes of soil physicochemical properties in Xitou, Central Taiwan. Geoderma 2016, 265, 187-195. [CrossRef]

88. Rossi, L.M.W.; Rapidel, B.; Roupsard, O.; Villatoro-sánchez, M.; Mao, Z.; Nespoulous, J.; Perez, J.; Prieto, I.; Roumet, C.; Metselaar, K.; et al. Sensitivity of the landslide model LAPSUS_LS to vegetation and soil parameters. Ecol. Eng. 2017, 109, 249-255. [CrossRef]

89. Thomas, M.A.; Mirus, B.B.; Collins, B.D.; Lu, N.; Godt, J.W. Variability in soil-water retention properties and implications for physics-based simulation of landslide early warning criteria. Landslides 2018, 15, 1265-1277. [CrossRef]

90. Chen, W.; Sun, Z.; Han, J. Landslide Susceptibility Modeling Using Integrated Ensemble Weights of Evidence with Logistic Regression and Random Forest Models. Appl. Sci. 2019, 9, 171. [CrossRef]

91. Bièvre, G.; Jongmans, D.; Goutaland, D.; Pathier, E.; Zumbo, V. Geophysical characterization of the lithological control on the kinematic pattern in a large clayey landslide (Avignonet, French Alps). Landslides 2016, 13, 423-436. [CrossRef]

92. Henriques, C.; Zêzere, J.L.; Marques, F. The role of the lithological setting on the landslide pattern and distribution. Eng. Geol. 2015, 189, 17-31. [CrossRef]

93. Gu, D.; Huang, D. A complex rock topple-rock slide failure of an anaclinal rock slope in the Wu Gorge, Yangtze River, China. Eng. Geol. 2016, 208, 165-180. [CrossRef]

94. Watakabe, T.; Matsushi, Y. Lithological controls on hydrological processes that trigger shallow landslides: Observations from granite and hornfels hillslopes in Hiroshima, Japan. CATENA 2019, 180, 55-68. [CrossRef]

95. Chung, C.-J.F.; Fabbri, A.G. Validation of Spatial Prediction Models for Landslide Hazard Mapping. Nat. Hazards 2003, 30, 451-472. [CrossRef] 
96. Pham, B.T.; Tien Bui, D.; Pourghasemi, H.R.; Indra, P.; Dholakia, M.B. Landslide susceptibility assesssment in the Uttarakhand area (India) using GIS: A comparison study of prediction capability of naïve bayes, multilayer perceptron neural networks, and functional trees methods. Theor. Appl. Climatol. 2017, 128, 255-273. [CrossRef]

97. Pradhan, B. A comparative study on the predictive ability of the decision tree, support vector machine and neuro-fuzzy models in landslide susceptibility mapping using GIS. Comput. Geosci. 2013, 51, 350-365. [CrossRef]

98. Pham, B.T. A Novel Classifier Based on Composite Hyper-cubes on Iterated Random Projections for Assessment of Landslide Susceptibility. J. Geol. Soc. India 2018, 91, 355-362. [CrossRef]

99. Pourghasemi, H.R.; Pradhan, B.; Gokceoglu, C. Application of fuzzy logic and analytical hierarchy process (AHP) to landslide susceptibility mapping at Haraz watershed, Iran. Nat. Hazards 2012, 63, 965-996. [CrossRef]

100. Tsangaratos, P.; Ilia, I. Comparison of a logistic regression and Naïve Bayes classifier in landslide susceptibility assessments: The influence of models complexity and training dataset size. CATENA 2016, 145, 164-179. [CrossRef]

101. Ford, A.; Miller, J.M.; Mol, A.G. A Comparative Analysis of Weights of Evidence, Evidential Belief Functions, and Fuzzy Logic for Mineral Potential Mapping Using Incomplete Data at the Scale of Investigation. Nat. Resour. Res. 2016, 25, 19-33. [CrossRef]

102. Fagin, T.D.; Hoagland, B.W. Patterns from the past: Modeling Public Land Survey witness tree distributions with weights-of-evidence. Plant Ecol. 2011, 212, 207-217. [CrossRef]

103. Shafizadeh-Moghadam, H.; Tayyebi, A.; Helbich, M. Transition index maps for urban growth simulation: Application of artificial neural networks, weight of evidence and fuzzy multi-criteria evaluation. Environ. Monit. Assess. 2017, 189, 300. [CrossRef]

104. Wang, Y.; Zhang, M.-S.; Xue, Q.; Wu, S.-D. Risk-based evaluation on geological environment carrying capacity of mountain city-A case study in Suide County, Shaanxi Province, China. J. Mt. Sci. 2018, 15, 2730-2740. [CrossRef]

105. Deng, M. A Conditional Dependence Adjusted Weights of Evidence Model. Nat. Resour. Res. 2009, 18, 249. [CrossRef]

106. Weed, D.L. Weight of evidence: A review of concept and methods. Risk Anal. 2005, 25, 1545-1557. [CrossRef] [PubMed]

107. Cheng, Q. BoostWofE: A New Sequential Weights of Evidence Model Reducing the Effect of Conditional Dependency. Math. Geosci. 2015, 47, 591-621. [CrossRef]

108. Bronevich, A.G.; Karkishchenko, A.N. The structure of fuzzy measure families induced by upper and lower probabilities. In Statistical Modeling, Analysis and Management of Fuzzy Data; Bertoluzza, C., Gil, M.-Á., Ralescu, D.A., Eds.; Physica-Verlag HD: Heidelberg, Germany, 2002; pp. 160-172. [CrossRef]

109. Dempster, A.P. Upper and Lower Probabilities Induced by a Multivalued Mapping. In Classic Works of the Dempster-Shafer Theory of Belief Functions; Yager, R.R., Liu, L., Eds.; Springer: Berlin/Heidelberg, Germany, 2008; pp. 57-72. [CrossRef]

110. Carranza, E.J.M. Data-Driven Evidential Belief Modeling of Mineral Potential Using Few Prospects and Evidence with Missing Values. Nat. Resour. Res. 2015, 24, 291-304. [CrossRef]

111. Harrison, K.E.; Srivastava, R.P.; Plumlee, R.D. Auditors' Evaluations of Uncertain Audit Evidence: Belief Functions versus Probabilities. In Belief Functions in Business Decisions; Srivastava, R.P., Mock, T.J., Eds.; Physica-Verlag HD: Heidelberg, Germany, 2002; pp. 161-183. [CrossRef]

112. Hong, H.; Kornejady, A.; Soltani, A.; Termeh, S.V.R.; Liu, J.; Zhu, A.X.; Ahmad, B.B.; Wang, Y. Landslide susceptibility assessment in the Anfu County, China: Comparing different statistical and probabilistic models considering the new topo-hydrological factor (HAND). Earth Sci. Inform. 2018, 11, 605-622. [CrossRef]

113. Pradhan, A.M.S.; Kim, Y.-T. Spatial data analysis and application of evidential belief functions to shallow landslide susceptibility mapping at Mt. Umyeon, Seoul, Korea. Bull. Eng. Geol. Environ. 2017, 76, 1263-1279. [CrossRef]

114. Wang, Q.; Li, W.; Wu, Y.; Pei, Y.; Xing, M.; Yang, D. A comparative study on the landslide susceptibility mapping using evidential belief function and weights of evidence models. J. Earth Syst. Sci. 2016, 125, 645-662. [CrossRef] 
115. Constantin, M.; Bednarik, M.; Jurchescu, M.C.; Vlaicu, M. Landslide susceptibility assessment using the bivariate statistical analysis and the index of entropy in the Sibiciu Basin (Romania). Environ. Earth Sci. 2011, 63, 397-406. [CrossRef]

116. Singh, V.A.; Pathak, P.; Pandey, P. Monitoring the Teaching_Learning Process via an Entropy Based Index. In Proceedings of Econophysics and Economics of Games, Social Choices and Quantitative Techniques; Springer: Milano, Italy, 2010; pp. 139-146.

117. Das, A. Logistic Regression. In Encyclopedia of Quality of Life and Well-Being Research; Michalos, A.C., Ed.; Springer: Dordrecht, The Netherland, 2014; pp. 3680-3682. [CrossRef]

118. Moon, K.-W. Logistic Regression. In Learn ggplot2 Using Shiny App; Moon, K.-W., Ed.; Springer International Publishing: Cham, Switzerland, 2016; pp. 51-54. [CrossRef]

119. Raja, N.B.; Çiçek, I.; Türkoğlu, N.; Aydin, O.; Kawasaki, A. Correction to: Landslide susceptibility mapping of the Sera River Basin using logistic regression model. Nat. Hazards 2018, 91, 1423. [CrossRef]

120. Meten, M.; Bhandary, N.P.; Yatabe, R. GIS-based frequency ratio and logistic regression modelling for landslide susceptibility mapping of Debre Sina area in central Ethiopia. J. Mt. Sci. 2015, 12, 1355-1372. [CrossRef]

121. Weisburd, D.; Britt, C. Logistic Regression. In Statistics in Criminal Justice; Weisburd, D., Britt, C., Eds.; Springer: Boston, MA, USA, 2014; pp. 548-600. [CrossRef]

122. Pradhan, B. Manifestation of an advanced fuzzy logic model coupled with Geo-information techniques to landslide susceptibility mapping and their comparison with logistic regression modelling. Environ. Ecol. Stat. 2011, 18, 471-493. [CrossRef]

123. Talaei, R. Landslide susceptibility zonation mapping using logistic regression and its validation in Hashtchin Region, northwest of Iran. J. Geol. Soc. India 2014, 84, 68-86. [CrossRef]

124. Chen, W.; Pradhan, B.; Li, S.; Shahabi, H.; Rizeei, H.M.; Hou, E.; Wang, S. Novel Hybrid Integration Approach of Bagging-Based Fisher's Linear Discriminant Function for Groundwater Potential Analysis. Nat. Resour. Res. 2019. [CrossRef]

125. Bui, D.T.; Ngo, P.-T.T.; Pham, T.D.; Jaafari, A.; Minh, N.Q.; Hoa, P.V.; Samui, P. A novel hybrid approach based on a swarm intelligence optimized extreme learning machine for flash flood susceptibility mapping. CATENA 2019, 179, 184-196. [CrossRef]

126. Toebe, M.; Cargnelutti Filho, A. Multicollinearity in path analysis of maize (Zea mays L.). J. Cereal Sci. 2013, 57, 453-462. [CrossRef]

127. International Business Machines Corporation (IBM). SPSS Desktop: Release 22.0; International Business Machines Corporation: Armonk, NY, USA, 2013.

128. Chen, W.; Shahabi, H.; Zhang, S.; Khosravi, K.; Shirzadi, A.; Chapi, K.; Pham, T.B.; Zhang, T.; Zhang, L.; Chai, H.; et al. Landslide Susceptibility Modeling Based on GIS and Novel Bagging-Based Kernel Logistic Regression. Appl. Sci. 2018, 8, 2540. [CrossRef]

129. Pourghasemi, H.R.; Rossi, M. Landslide susceptibility modeling in a landslide prone area in Mazandarn Province, north of Iran: A comparison between GLM, GAM, MARS, and M-AHP methods. Theor. Appl. Climatol. 2017, 130, 609-633. [CrossRef]

130. Pham, B.T.; Tien Bui, D.; Prakash, I.; Dholakia, M.B. Hybrid integration of Multilayer Perceptron Neural Networks and machine learning ensembles for landslide susceptibility assessment at Himalayan area (India) using GIS. CATENA 2017, 149, 52-63. [CrossRef]

131. Samia, J.; Temme, A.; Bregt, A.; Wallinga, J.; Guzzetti, F.; Ardizzone, F.; Rossi, M. Do landslides follow landslides? Insights in path dependency from a multi-temporal landslide inventory. Landslides 2017, 14, 547-558. [CrossRef]

132. Xu, D.; Peng, L.; Liu, S.; Wang, X. Influences of Risk Perception and Sense of Place on Landslide Disaster Preparedness in Southwestern China. Int. J. Disaster Risk Sci. 2018, 9, 167-180. [CrossRef]

133. Devkota, K.C.; Regmi, A.D.; Pourghasemi, H.R.; Yoshida, K.; Pradhan, B.; Ryu, I.C.; Dhital, M.R.; Althuwaynee, O.F. Landslide susceptibility mapping using certainty factor, index of entropy and logistic regression models in GIS and their comparison at Mugling-Narayanghat road section in Nepal Himalaya. Nat. Hazards 2013, 65, 135-165. [CrossRef]

134. Arabameri, A.; Pradhan, B.; Rezaei, K.; Sohrabi, M.; Kalantari, Z. GIS-based landslide susceptibility mapping using numerical risk factor bivariate model and its ensemble with linear multivariate regression and boosted regression tree algorithms. J. Mt. Sci. 2019, 16, 595-618. [CrossRef] 
135. Chen, W.; Pourghasemi, H.R.; Panahi, M.; Kornejady, A.; Wang, J.; Xie, X.; Cao, S. Spatial prediction of landslide susceptibility using an adaptive neuro-fuzzy inference system combined with frequency ratio, generalized additive model, and support vector machine techniques. Geomorphology 2017, 297, 69-85. [CrossRef]

136. Jaafari, A.; Najafi, A.; Pourghasemi, H.R.; Rezaeian, J.; Sattarian, A. GIS-based frequency ratio and index of entropy models for landslide susceptibility assessment in the Caspian forest, northern Iran. Int. J. Environ. Sci. Technol. 2014, 11, 909-926. [CrossRef]

137. Abedini, M.; Tulabi, S. Assessing LNRF, FR, and AHP models in landslide susceptibility mapping index: A comparative study of Nojian watershed in Lorestan province, Iran. Environ. Earth Sci. 2018, 77, 405. [CrossRef]

138. Demir, G. Landslide susceptibility mapping by using statistical analysis in the North Anatolian Fault Zone (NAFZ) on the northern part of Suşehri Town, Turkey. Nat. Hazards 2018, 92, 133-154. [CrossRef]

139. Chou, W.-C.; Lin, W.-T.; Lin, C.-Y. Vegetation recovery patterns assessment at landslides caused by catastrophic earthquake: A case study in central Taiwan. Environ. Monit. Assess. 2008, 152, 245. [CrossRef]

140. Gonzalez-Ollauri, A.; Mickovski, S.B. Hydrological effect of vegetation against rainfall-induced landslides. J. Hydrol. 2017, 549, 374-387. [CrossRef]

141. Neto, C.; Cardigos, P.; Oliveira, S.C.; Zêzere, J.L. Floristic and vegetation successional processes within landslides in a Mediterranean environment. Sci. Total Environ. 2017, 574, 969-981. [CrossRef]

(C) 2019 by the authors. Licensee MDPI, Basel, Switzerland. This article is an open access article distributed under the terms and conditions of the Creative Commons Attribution (CC BY) license (http://creativecommons.org/licenses/by/4.0/). 